\title{
The Revolutionary 2012 Kansas Tax Act
}

\author{
Martin B. Dickinson, ${ }^{*}$ Stephen W. Mazza ${ }^{* *}$ \& Michael R. Keenan ${ }^{* * *}$ \\ PART ONE: INTRODUCTION
}

On May 22, 2012, Kansas Governor Sam Brownback signed into law Senate Substitute for House Bill 2117 (HB 2117), ${ }^{1}$ amending the Kansas tax laws. The legislation, generally effective January 1, 2013, makes revolutionary changes in the Kansas income tax. It compresses the existing three rate brackets to two and lowers the top rate from $6.45 \%$ to $4.9 \%$. Most importantly, it exempts from the Kansas income tax many types and sources of income.

HB 2117 has received national attention, both favorable ${ }^{2}$ and unfavorable. ${ }^{3}$ Within Kansas, there remains controversy regarding the procedure used to adopt HB 2117, the impact of HB 2117 on government revenues, ${ }^{4}$ and the effect HB 2117 will have on distribution of the tax burden among Kansans. ${ }^{5}$ While the legislation is detailed, the Kansas Department of Revenue has already found it necessary to issue numerous interpretations. Even with this guidance, many questions remain unanswered and will likely require the Kansas legislature to revisit the tax package during the next legislative session.

The legislation raises several constitutional and administrative law questions that other commentators may wish to address, but the purpose

* Robert A. Schroeder Professor of Law, University of Kansas School of Law.

** Dean and Professor of Law, University of Kansas School of Law.

*** J.D. candidate 2013, University of Kansas School of Law. Mr. Keenan appreciates the support provided by the Wichita firm of Fleeson, Gooing, Coulson \& Kitch LLC for his work on this article while serving as a law clerk during the summer of 2012.

1. Act of May 22, 2012, ch. 135, 2012 Kan. Sess. Laws 1041. The few provisions that have an effective date other January 1, 2013, are noted throughout the Article.

2. See, e.g., Editorial, What's Right with Kansas, WALL ST. J., May 30, 2012, http://online.wsj.com/article/SB10001424052702304070304577394340998558490.html.

3. See, e.g., Inst. ON TAXATION \& ECON. POLICY, TAX BILl Signed By GovernoR BROWNBACK MAKES KANSAS AN OUTLIER (May 24, 2012), http://www.itep.org/pdf/KSFamilies. pdf; Martin A. Sullivan, Economic Analysis: Brownback's Derailed Tax Reform Becomes a Fiscal Train Wreck, 135 TAX NoTES 1193 (2012).

4. See infra Part V.A.

5. See infra Part V.B. 
of this Article is somewhat more modest. Part II provides a technical description and analysis of HB 2117. It details revisions affecting not only the Kansas individual income tax, the part of the legislation that has received the most attention, but also other tax provisions impacted by the new legislation. Part III identifies portions of HB 2117 that may lend themselves to exploitation or "gaming" by parties seeking to reduce their Kansas tax liability. Part IV identifies several unresolved questions that should be addressed by the Kansas Legislature, including a potential ambiguity in the statutory language that may convert what many observers viewed as an exemption into merely a deferral provision. Part $\mathrm{V}$ addresses the fiscal impact of HB 2117, the effect of HB 2117 on distribution of the Kansas tax burden, and related policy issues.

The authors appreciate the generous assistance of Richard Cram, Director of Policy and Research for the Kansas Department of Revenue, in determining the Department's interpretation and implementation of HB 2117.

PART TWO: DESCRIPTION OF HB 2117

\section{A. Individual Income Tax}

As a general rule, Kansas taxes its residents on all their income and taxes nonresidents on their Kansas source income. ${ }^{6}$ The income tax base is Kansas taxable income, which is calculated by subtracting allowable deductions (standard or itemized) and the personal exemption from Kansas adjusted gross income (AGI). ${ }^{7}$ Like most states that have an income tax, the state measure of AGI starts with the taxpayer's federal AGI. ${ }^{8}$ In general, federal AGI is net economic income after deducting the expenses of earning the income. ${ }^{9}$ The modifications necessary to convert federal AGI to Kansas AGI include more than forty additions and subtractions. ${ }^{10}$ As explained below, the new legislation alters the income tax rates and adds an entirely new subtraction that will allow many taxpayers to exempt an unlimited amount of income from Kansas tax.

6. KAN. STAT. ANN. § 79-32,110 (Supp. 2011).

7. Id. § 79-32,116 (1997).

8. Id. § 79-32,117(a) (Supp. 2011).

9. See I.R.C. § 62(a)(1) (2006).

10. See KAN. StAT. AnN. § 79-32,117. 


\section{Tax Rates}

HB 2117 lowers income tax rates at all levels. The legislation replaces the existing three-tier rate structure with a two-tier structure. ${ }^{11}$

The following rates apply to married taxpayers filing joint returns:

\begin{tabular}{|l|l|}
\hline Current rates (2012) & \\
\hline If the taxable income is: & The tax is: \\
\hline Not over $\$ 30,000$ & $3.5 \%$ \\
\hline $\begin{array}{l}\text { Over } \$ 30,000 \text { but not over } \\
\$ 60,000\end{array}$ & $\begin{array}{l}\$ 1,050 \text { plus } 6.25 \% \text { of } \\
\text { excess over } \$ 30,000\end{array}$ \\
\hline Over $\$ 60,000$ & $\begin{array}{l}\$ 2,925 \text { plus } 6.45 \% \text { of } \\
\text { excess over } \$ 60,000\end{array}$ \\
\hline Post-2012 rates $^{13}:$ & The tax is: \\
\hline If the taxable income is: & $3.0 \%$ \\
\hline Not over $\$ 30,000$ & $\begin{array}{l}\$ 900 \text { plus } 4.9 \% \text { of excess } \\
\text { over } \$ 30,000\end{array}$ \\
\hline Over $\$ 30,000$ & \\
\hline
\end{tabular}

For all other individuals, as well as estates and trusts, these rates apply:

\begin{tabular}{|l|l|}
\hline Current rates (2012) $^{14}:$ & \\
\hline If the taxable income is: & The tax is: \\
\hline Not over $\$ 15,000$ & $3.5 \%$ \\
\hline $\begin{array}{l}\text { Over } \$ 15,000 \text { but not over } \\
\$ 30,000\end{array}$ & $\begin{array}{l}\$ 525 \text { plus } 6.25 \% \text { of excess } \\
\text { over } \$ 15,000\end{array}$ \\
\hline Over $\$ 30,000$ & $\begin{array}{l}\$ 1,462.50 \text { plus } 6.45 \% \text { of } \\
\text { excess over } \$ 30,000\end{array}$ \\
\hline
\end{tabular}

11. See Act of May 22, 2012, ch. 135, sec. 10, § 79-32,110, 2012 Kan. Sess. Laws 1041, $1050-51$.

12. KAN. STAT. ANN. § 79-32,110(a)(1).

13. Sec. 10, § 79-32,110(a)(1)(B), 2012 Kan. Sess. Laws at 1050-51.

14. KAN. StAT. ANN. § 79-32,110(a)(2)(B). 


\begin{tabular}{|l|l|}
\hline Post-2012 $^{\text {rates }}{ }^{15}:$ & \\
\hline If the taxable income is: & The tax is: \\
\hline Not over $\$ 15,000$ & $3.0 \%$ \\
\hline Over $\$ 15,000$ & $\begin{array}{l}\$ 450 \text { plus } 4.9 \% \text { of excess } \\
\text { over } \$ 15,000\end{array}$ \\
\hline
\end{tabular}

\section{Itemized and Standard Deductions}

Under current law taxpayers can subtract from their Kansas AGI either the standard deduction ${ }^{16}$ or itemized deductions (provided the taxpayer itemized on the federal return). ${ }^{17}$ The statutory language of HB 2117 is unclear on the question of whether taxpayers may continue to itemize their deductions when determining Kansas AGI. HB 2117 eliminates the reference to itemized deductions in section 79-32,118 of the Kansas Statutes, ${ }^{18}$ suggesting that itemized deductions are no longer permissible for Kansas income tax purposes. However, section 7932,120, which expressly permits itemization, is not modified or repealed by the new legislation. The final Supplemental Note prepared by the Legislative Research Department for HB 2117 maintains that the legislature did not intend to eliminate itemization. ${ }^{19}$ Kansas Department of Revenue Notice 12-07 states that the Department will continue to interpret section 79-32,120 as permitting itemization by Kansas taxpayers who also itemize their deductions for federal purposes. ${ }^{20}$

Taxpayers who do not itemize deductions may claim the standard deduction, the amount of which HB 2117 increases for both married filing jointly and head of household returns, but not for returns filed by single taxpayers. ${ }^{21}$

\footnotetext{
15. Sec. 10, § 79-32,110(a)(2)(B), 2012 Kan. Sess. Laws at 1051.

16. KAN. STAT. ANN. § 79-32,119.

17. Id. § 79-32,120(a).

18. Sec. 13, § 79-32,118, 2012 Kan. Sess. Laws at 1059.

19. Kan. Legislative Research Dep’t, Updated Supplemental note on Senate SUBSTITUTE FOR HOUSE BILL NO. 2117, at 3-2117 (2012), http://www.kslegislature.org/li/b2011_12 /measures/documents/supp_note_hb2117_04_0000.pdf.

20. KAN. DeP'T OF REVENUE, NOTICE 12-07: ITEMIZED DEDUCTIONS FOR INDIVIDUAL INCOME TAX 2 (2012), http://www.ksrevenue.org/taxnotices/notice12-07.pdf [hereinafter NOTICE 12-07].

21. Sec. 14, § 79-32,119, 2012 Kan. Sess. Laws at 1059-60.
} 


\begin{tabular}{|l|l|l|}
\hline Status: & Current (2012) & 22013 and after $^{23}:$ \\
\hline Single & $\$ 3,000$ & $\$ 3,000$ \\
\hline Married & $\$ 6,000$ & $\$ 9,000$ \\
\hline Head of household & $\$ 4,500$ & $\$ 9,000$ \\
\hline
\end{tabular}

As under existing law, higher standard deduction amounts are available if the taxpayer is over sixty-five, blind, or both. ${ }^{24}$

\section{Credits and Deductions Repealed}

The new legislation repeals the following credits, which would otherwise reduce the taxpayer's Kansas income tax liability dollar for dollar:

Household and dependent care expenses per section 79-32,111a. ${ }^{25}$

Expenditures to provide disabled access per section 79-32,176. ${ }^{26}$

Adoption expenses per section 79-32,202. ${ }^{27}$

Provision of health insurance for a member of the Kansas National Guard per section 79-32,213. ${ }^{28}$

Contributions to the Kansas Law Enforcement Training Center per section $79-32,242 .^{29}$

22. KAN. STAT. ANN. § 79-32,119 (Supp. 2011).

23. Sec. 14, § 79-32,119, 2012 Kan. Sess. Laws at 1059-60.

24. See id.

25. Sec. 40, 2012 Kan. Sess. Laws at 1088 (repealing KAN. STAT. ANN. § 79-32,111a); KAN. Dep'T of ReVEnue, Notice 12-04: CRedits and SubTraction Modification Repealed 1 (2012), http://www.ksrevenue.org/taxnotices/notice12-04.pdf [hereinafter NOTICE 12-04].

26. Sec. 40, 2012 Kan. Sess. Laws at 1088 (repealing KAN. STAT. ANN. § 79-32,176); NotICE 12-04, supra note 25, at 1.

27. Sec. 40, 2012 Kan. Sess. Laws at 1088 (repealing Kan. STAT. ANN. § 79-32,202); NoticE 12-04, supra note 25 , at 1 .

28. Sec. 40, 2012 Kan. Sess. Laws at 1088 (repealing Kan. StAT. AnN. § 79-32,213); Notice $12-04$, supra note 25 , at 1 .

29. Sec. 40, 2012 Kan. Sess. Laws at 1088 (repealing KAN. STAT. ANN. § 79-32,242); NotiCE 12-04, supra note 25 , at 1. 
Under current law, payments for long-term care insurance, up to $\$ 1,000$ per year, can be subtracted in determining Kansas AGI. ${ }^{30}$ HB 2117 repeals this subtraction. ${ }^{31}$

\section{Exempt Income}

The most important and complex part of HB 2117 is a provision that allows taxpayers to exempt from the income tax selected categories of income. $^{32}$ The exemption operates by authorizing the taxpayer to subtract income from certain sources when determining Kansas AGI. ${ }^{33}$

Section 79-32,117(c) lists the items that are subtracted in determining Kansas AGI. HB 2117 adds an entirely new subtraction item-paragraph (xx). ${ }^{34}$ Paragraph $(\mathrm{xx})$ reads as follows:

(c) There shall be subtracted from federal adjusted gross income:

$\cdots$

(xx) For all taxable years beginning after December 31, 2012, the amount of any: (1) Net profit from business as determined under the federal internal revenue code and reported from schedule $\mathrm{C}$ and on line 12 of the taxpayer's form 1040 federal individual income tax return; (2) net income from rental real estate, royalties, partnerships, S corporations, estates, trusts, residual interest in real estate mortgage investment conduits and net farm rental as determined under the federal internal revenue code and reported from schedule $\mathrm{E}$ and on line 17 of the taxpayer's form 1040 federal individual income tax return; and (3) net farm profit as determined under the federal internal revenue code and reported from schedule $\mathrm{F}$ and on line 18 of the taxpayer's form 1040 federal income tax return; all to the extent included in the taxpayer's federal adjusted gross income. For purposes of this subsection, references to the federal form 1040 and federal schedule C, schedule E, and schedule F, shall be to such form and schedules as they existed for tax year 2011 and as revised thereafter by the internal revenue service. $^{35}$

30. KAN. StaT. ANN. § 79-32,117(c)(xvi) (Supp. 2011).

31. Sec. 40, 2012 Kan. Sess. Laws at 1088 (repealing Kan. STAt. AnN. § 79-32,117); Notice $12-04$, supra note 25 , at 1 .

32. Sec. 12, § 79-32,117, 2012 Kan. Sess. Laws at 1052-59.

33. See id. § 79-32,117(c), at 1055-59.

34. Id. § 79-32,117(c)(xx), at 1058-59.

35. Id. at 1055, 1058-59 (italics omitted). 
The effect of this new subtraction item is to exempt from Kansas income tax each of the three categories of income described in paragraph (xx). For example, assume that Tom's only income is $\$ 100,000$ of farm income that falls within the category of "net farm profit" reported on Schedule F. Tom's federal AGI will be $\$ 100,000$. Part (3) of paragraph (xx) grants Tom a \$100,000 subtraction in determining Kansas AGI. Therefore, Tom's Kansas AGI is $\$ 100,000$ less $\$ 100,000$, or zero. Tom's Kansas taxable income will be zero as well, and Tom will owe no Kansas tax. By virtue of the new subtraction, all of Tom's farm income is exempt from Kansas income tax.

\section{a. Category (1): Independent Contractor Income.}

New paragraph 79-32,117(c)(xx)(1) exempts net profit from business activities reported on Schedule C of Form 1040, the federal income tax return for individuals. ${ }^{36}$ Businesses conducted as sole proprietorships, including individuals acting as independent contractors, use Schedule C to report income and loss. ${ }^{37}$ Employees may not report their wage earnings on Schedule C. ${ }^{38}$ As a general matter, if a business treats a worker as an employee, reporting the worker's compensation on a Form $\mathrm{W}-2$, the worker must report her compensation on line 7 of Form 1040. ${ }^{39}$ Therefore, employee compensation does not qualify for the paragraph $(\mathrm{xx})$ exclusion, ${ }^{40}$ and an employee must pay Kansas income tax on her income.

As explained in Part III, the distinction between a service provider acting as an employee (who does not qualify for the exclusion) and a service provider acting as an independent contractor (who does qualify for the exclusion) can be difficult to draw. An individual who qualifies as a "statutory employee" may report income and expense on Schedule C

36. Id. at 1058-59.

37. See Internal Revenue Serv., 2011 Instructions for Schedule C, Profit or Loss FROM BUSINESS C-1 (2011) [hereinafter 2011 InSTRUCTIONS FOR SCHEDULE C], available at http://www.irs.gov/pub/irs-pdf/i1040sc.pdf.

38. See id. (noting that only sole proprietorships, statutory employees, and single member limited liability companies "not treated as ... separate entit[ies] for federal income tax purposes" can use Schedule C).

39. See InTERnal REVEnUe SERV., 1040 InStRUCtions 2011, at 19 (2011), http://www.irs. gov/pub/irs-pdf/i1040.pdf.

40. Kan. DeP'T of Revenue, Notice 12-11: Kansas Income Tax Changes to Addition AND SUBTRACTION MODIFICATIONS INCOME EXEMPT FROM KANSAS TAX 3 (2012), http://www.ks revenue.org/taxnotices/notice12-11.pdf [hereinafter NOTICE 12-11]. 
and thereby qualify for the paragraph (xx) subtraction. ${ }^{41}$ A "statutory employee" is a worker who would ordinarily be considered an independent contractor but who, by reason of Internal Revenue Code (IRC) $\S 3121(d)(3)$, is treated as an employee for purposes of employment taxes. ${ }^{42}$ Examples are full-time life insurance sales persons and full-time traveling sales persons. ${ }^{43}$

Income generated by a single-member limited liability company (LLC) can also qualify for the exclusion. If the taxpayer is the only member of an LLC that has not elected to be taxed as a corporation, the entity is ignored for federal tax purposes. ${ }^{44}$ Therefore, the taxpayer may report income using Schedule $\mathrm{C}^{45}$ and qualify for the paragraph (xx) subtraction. ${ }^{46}$

The Department of Revenue takes the position that only income "properly reported" on Schedule C qualifies for the paragraph (xx) subtraction. ${ }^{47}$ Therefore, Schedule $\mathrm{C}$ and the accompanying instructions are determinative. ${ }^{48}$ This has the effect of limiting the scope of the exclusion. For instance, the 2011 Schedule C instructions provide that casualty or theft gains and losses involving business property are to be reported on Form 4684, not Schedule C. ${ }^{49}$ Thus, a casualty or theft gain does not qualify for the paragraph (xx) subtraction. ${ }^{50}$ Similarly, the 2011 Schedule C instructions provide that "sales, exchanges, and involuntary conversions ... of trade or business property" are to be reported on Form 4797, not Schedule C. ${ }^{51}$ For example, gain on disposition of a building or equipment used in a trade or business cannot be reported on Schedule $\mathrm{C}$ and therefore will not qualify for the paragraph (xx) subtraction. ${ }^{52}$

As explained in Part II.A.4.b.viii, the Department of Revenue takes the position that, in general, interest, dividends, and capital gain cannot

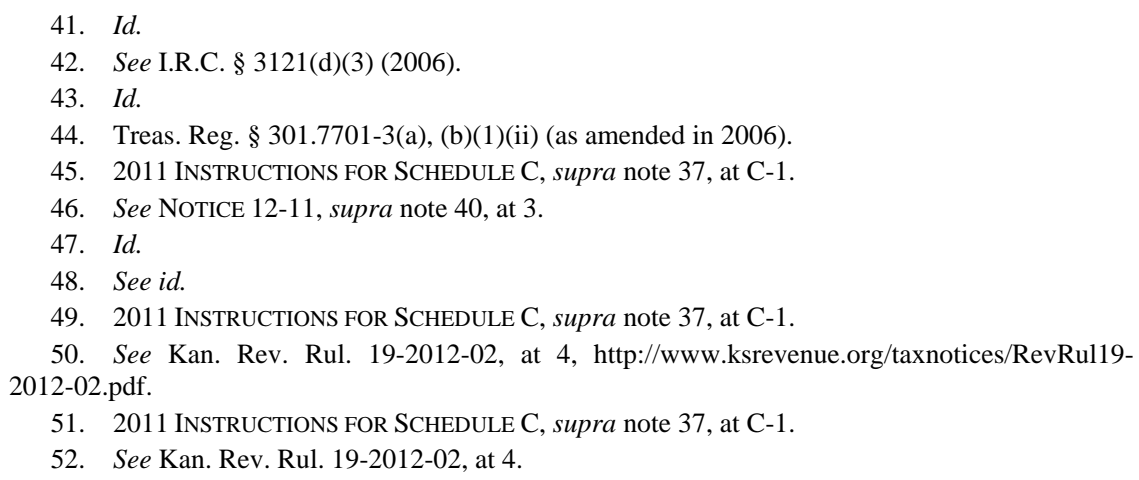


qualify for the paragraph (xx) subtraction. ${ }^{53}$ There is an important exception, however. If the taxpayer is in the trade or business of lending money, the interest income can be reported as "other income" on Schedule C and thereby qualify for the paragraph (xx) subtraction. ${ }^{54}$

\section{b. Category (2): Income from Certain Sources or from Certain Entities}

\section{i. Income from Certain Sources}

Income from certain specified sources qualifies for the paragraph (xx) subtraction and is therefore effectively exempt from Kansas income tax. The qualifying sources of income are broad: "rental real estate, royalties,... residual interests in real estate mortgage investment conduits and net farm rental." 55 All of this income is reported on Schedule E of federal Form $1040 .^{56}$

Under the 2011 instructions for Schedule E, the "rental real estate" category includes not just rent from real property but also rent from personal property rented with real estate. ${ }^{57}$ The royalties category includes (1) "royalties from oil, gas, or mineral properties (not including operating interests)," (2) royalties from copyrights, and (3) royalties from patents. ${ }^{58}$

The net farm rental income category is also broadly defined. The 2011 instructions for Schedule E state that if the taxpayer does not materially participate in the farming enterprise, the farm rental income is to be reported on Form 4835. ${ }^{59}$ However, Form 4835 totals are ultimately entered on line 40 of Schedule E. ${ }^{60}$ Therefore, farm rental income should qualify for the paragraph (xx) subtraction even if the

\footnotetext{
53. Id. at 3-4.

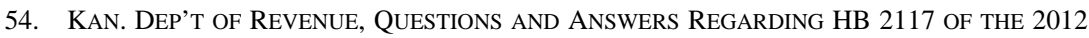
LEGISLATIVE SESSION 5 (Nov. 2012), http://www.ksrevenue.org/pdf/HB2117QuestionsAnswers.pdf [hereinafter QUESTIONS AND ANSWERS REGARDING HB 2117].

55. Act of May 22, 2012, ch. 135, sec. 12, § 79-32,117(c)(xx)(2), 2012 Kan. Sess. Laws 1041,

56. Id.

57. INTERNAL REVENUE SERV., 2011 InSTRUCTIONS FOR SCHEdUle E (Form 1040), SUPPLEMENTAL INCOME AND LOSS E-4 (2011), http://www.irs.gov/pub/irs-pdf/i1040se.pdf [hereinafter 2011 INSTRUCTIONS FOR SCHEDULE E].

58. Id. at $\mathrm{E}-5$.

59. Id.

60. INTERNAL REVENUE SERV., SCHEDULE E (FORM 1040): SUPPLEMENTAL INCOME AND LOSS (2011), http://www.irs.gov/pub/irs-pdf/f1040se.pdf.
} 1058. 
taxpayer does not materially participate in the farming enterprise. As explained below, paragraph (xx) also creates an exclusion for "net farm income," as compared with farm rental income. Taxpayers use Schedule $\mathrm{F}$ to report income from farming operations in which the taxpayer materially participates. ${ }^{61}$

\section{ii. Income from Certain Entities}

Income from certain entities also qualifies for the paragraph (xx) subtraction. The qualifying entities specified in the statute are partnerships, S corporations, estates, and trusts. ${ }^{62}$

For both federal and Kansas income tax purposes, partnerships and $\mathrm{S}$ corporations are "pass through" entities, and the income of the entity is automatically taxed to the partner or shareholder whether or not the income is distributed. ${ }^{63}$ The practical result of part (2) of paragraph (xx), therefore, is to free partners and S corporation shareholders of liability for tax on their shares of entity income. Assume, for example, that a law firm partnership earns $\$ 1,000,000$, and Bill is a $10 \%$ partner. Bill must include \$100,000 in federal and Kansas AGI. For Kansas purposes, however, Bill is entitled to a paragraph (xx) subtraction of $\$ 100,000$, reducing his Kansas AGI to zero and eliminating any Kansas income tax liability.

LLCs are not expressly mentioned in the statute, but income from an LLC will nevertheless qualify for the paragraph (xx) subtraction if the LLC is treated as a partnership for federal tax purposes. ${ }^{64}$ An LLC with more than one member will be treated as a partnership for federal tax purposes unless the entity elects otherwise. ${ }^{65}$ Kansas law provides that if an LLC is treated as a partnership for federal income tax purposes, it is treated as a partnership for Kansas tax purposes as well. ${ }^{66}$ Consequently, members who derive income from an LLC will qualify for the

61. See Internal Revenue Serv., 2011 Instructions for Schedule F, Profit or Loss FROM FARMING F-1 (2011), http://www.irs.gov/pub/irs-pdf/i1040sf.pdf [hereinafter 2011 INSTRUCTIONS FOR SCHEDULE F].

62. Act of May 22, 2012, ch. 135, sec. 12, § 79-32,117(c)(xx)(2), 2012 Kan. Sess. Laws 1041, 1058.

63. I.R.C. §§ 701, 702, 1363, 1366 (2006); KAN. STAT. ANN. §§ 79-32,129 to -32,130, -32,139 (1997).

64. NOTICE $12-11$, supra note 40 , at 4.

65. Treas. Reg. § 301-7701-3(b)(1)(i) (as amended in 2006).

66. KAN. STAT. ANN. § 17-76,138 (2007). 
exclusion. ${ }^{67}$ By comparison, a single-member LLC that has not elected to be taxed as a corporation is disregarded. ${ }^{68}$ Therefore, the single member can report the enterprise income on Schedule C or F and qualify for the paragraph (xx) subtraction. ${ }^{69}$

Some partners are entitled to "guaranteed payments," i.e., payments that are made to the partner regardless of the amount of partnership income. $^{70}$ Under federal income tax law, guaranteed payments are treated as if made to one who is not a partner, but only for certain limited purposes. $^{71}$ The Instructions for Schedule K-1 for partnerships directs that guaranteed payments be shown on line 28 of Form 1040 Schedule E. ${ }^{72}$ Therefore, guaranteed payments qualify for the paragraph (xx) subtraction. ${ }^{73}$

The paragraph (xx) subtraction applies only to the income allocable to each partner or S corporation shareholder under the pass through tax regime. What happens when that income is actually distributed to the partner or S corporation shareholder? Under federal law this is an entirely separate event for tax purposes. In the case of a partnership, taxation of distributions is governed by IRC $\S 731 .^{74}$ In the case of an S corporation, taxation of distributions is governed by IRC $\S 1368 .^{75}$ As explained in Part IV.B, below, the Kansas treatment of a distribution to a partner or S corporation shareholder remains uncertain.

\section{iii. Professional Corporations}

Many law firms are organized as professional corporations, and their Kansas income tax treatment under the new legislation will depend upon whether or not the entity makes an $\mathrm{S}$ election. If a professional corporation formed pursuant to section 17-2706 et seq. of the Kansas Statutes is used, the benefits of paragraph (xx) will not be available

67. All subsequent references in this Article to partnerships should be understood as including LLCs that are taxed as partnerships for federal income tax purposes.

68. Treas. Reg. § 301.7701-3(a)-(b).

69. Notice 12-11, supra note 40, at 3, 5 .

70. See I.R.C. § 707(c) (2006).

71. Id.

72. InTERnal ReVEnUe SeRV., 2011 PARTNER's Instructions For SCHEdUle K-1 (Form 1065) 7 (2012), http://www.irs.gov/pub/irs-pdf/i1065sk1.pdf [hereinafter INSTRUCTIONS FOR SCHEDULE K-1].

73. QUESTIONS AND ANSWERS REgARDING HB 2117, supra note 54, at 3.

74. I.R.C. § 731 (2006).

75. Id. § 1368 (Supp. IV 2007-2011). 
unless the corporation makes an $\mathrm{S}$ corporation election. ${ }^{76}$ If the corporation treats the professionals as employees and pays them salaries, the salaries will be fully taxed. ${ }^{77}$

\section{iv. Banks, Savings and Loan Associations, and Federal Savings Associations Organized as S Corporations}

Prior to enactment of HB 2117, section 79-32,117(c)(xiv) provided a special rule for shareholders in banks, savings and loan associations, and federal savings associations organized as $\mathrm{S}$ corporations. The shareholder was entitled to subtract from federal AGI any income of the entity that was not distributed to the shareholder as a dividend. ${ }^{78}$ The practical effect was to exempt shareholders in these entities from Kansas tax except to the extent earnings were actually distributed.

A new sentence added to paragraph (xiv) by HB 2117 provides that the paragraph (xiv) subtraction is no longer available to the extent the shareholder uses the paragraph $(\mathrm{xx})$ subtraction for $\mathrm{S}$ corporation shareholders generally. ${ }^{79}$ The purpose of this addition is simply to avoid a double subtraction of the same amount under both paragraphs (xx) and (xiv). ${ }^{80}$ The result is that shareholders in S corporation banks, savings and loan associations, and federal savings associations will be treated in the same way as shareholders in other $\mathrm{S}$ corporations.

\section{v. Nongrantor Trusts}

As a general rule, a trust is a separate entity for income tax purposes. $^{81}$ The income of some trusts, however, is taxed to the grantor because of the grantor's retention of benefits from or power over the trust. $^{82}$ The treatment of such "grantor trusts" is discussed in the

\footnotetext{
76. Notice $12-11$, supra note 40 , at 4 .

77. See supra Part II.A.4.a (noting that employee wages are not exempted from tax under paragraph (xx)).

78. KAN. STAT. ANN. § 79-32,117(c)(xiv) (Supp. 2011).

79. Act of May 22, 2012, ch. 135, sec. 12, § 79-32,117(c)(xiv), 2012 Kan. Sess. Laws 1041, 1057.

80. Kan. Dep'T of ReVenue, Notice 12-12: S CoRporations OWNing Banks, SAVings AND LOANS, OR FEDERAL SAVINGS ASSOCIATIONS 2 (2012), http://www.ksrevenue.org/tax notices/notice12-12.pdf.

81. See I.R.C. § 641(a) (2006).

82. See id. §§ 671-677.
} 
following Part II.A.4.b.vi. Trusts not subject to the grantor trust rules, or "nongrantor trusts," are addressed in this Part.

As to nongrantor trusts, the first question is whether the trust itself, as a taxpayer, can take advantage of the paragraph (xx) subtraction. The answer is "no." The paragraph (xx) subtraction exempts only income reported on Schedules C, E, or F of Form 1040, which are available only to individuals. Therefore, all income that is taxed to the trust rather than a beneficiary will remain subject to Kansas income tax. ${ }^{83}$ Some income that is taxed to the beneficiary rather than the trust, however, can qualify for the paragraph (xx) subtraction. ${ }^{84}$ As explained below, the exemption for income from a trust may make it advantageous to distribute rather than accumulate trust income.

Nongrantor trusts are typically categorized as either "simple" trusts or "complex" trusts. ${ }^{85}$ A simple trust is one in which all income is distributed or required to be distributed currently and there are no charitable beneficiaries. ${ }^{86}$ With a simple trust, the trust beneficiary is taxed on the trust income whether or not it is actually distributed. ${ }^{87}$ For both federal and Kansas purposes, the income retains the same character in the beneficiary's hands as in the hands of the trust. ${ }^{88}$ Therefore, the paragraph ( $\mathrm{xx}$ ) subtraction "applies to the beneficiary as if the beneficiary had received the income directly from the source that produced it." 89

With a complex trust, the trustee can accumulate income or distribute corpus. $^{90}$ The beneficiary is taxed on income actually distributed or required to be distributed. ${ }^{91}$ For both federal and Kansas purposes, the income generated by a complex trust also retains the same character in the beneficiary's hands as in the hands of the trust. ${ }^{92}$ Therefore, the

83. QUESTIONS AND ANSWERS REGARDING HB 2117, supra note 54, at 4.

84. See id. (noting that income from a trust recorded on a trust beneficiary's Schedule E would be eligible for a paragraph ( $\mathrm{xx}$ ) subtraction).

85. 1 William H. NeWTON, III, International InCOME TAX AND Estate Planning § 6:30 (2d ed. 2012) (citing I.R.C. $\S \S 651,661$ ).

86. Id. (citing I.R.C. § 651; Treas. Reg. § 1.651(a)-1 (1969)).

87. I.R.C. § 652(a)

88. Id. § 652(b); see Kan. Rev. Rul. 19-2012-02, at 2, http://www.ksrevenue.org/taxnotices/ RevRul19-2012-02.pdf (noting the federal rule and its application in Kansas tax law).

89. Kan. Rev. Rul. 19-2012-02, at 2.

90. See NEWTON, supra note 85, § 6:30 (“[A complex] trust may be authorized to accumulate income or to make charitable contributions.” (citing I.R.C. § 661)).

91. I.R.C. § 662(a)

92. I.R.C. § 662(b); see Kan. Rev. Rul. 19-2012-02, at 3. 
paragraph ( $\mathrm{xx}$ ) subtraction "applies to the beneficiary as if the beneficiary had received the income directly from the source that produced it." ${ }^{\text {"93 }}$

The benefit of the exemption for income received from a trust is greatly diminished by the Department of Revenue's position, discussed in Part II.A.4.b.viii below, that interest, dividends, and capital gain generally are not within the paragraph (xx) subtraction. ${ }^{94}$ As a result, much typical trust income will not qualify for the paragraph (xx) subtraction and will remain subject to Kansas income tax.

Income from a Real Estate Investment Trust (REIT) does not qualify for the paragraph (xx) subtraction. Income from a REIT is reported on lines 12, 17, or 18 of Form 1040, not on Schedules C, E, or F. ${ }^{95}$

\section{vi. Grantor Trusts}

For federal income tax purposes, the income of a "grantor trust" is treated as if received directly by the grantor, and the trust is ignored. ${ }^{96} \mathrm{~A}$ trust is treated as a grantor trust if the grantor or the grantor's spouse retains any of the powers described in IRC $\S \S 673-677,{ }^{97}$ which include power to revoke the trust. ${ }^{98}$ The typical grantor trust is a revocable trust that is intended to serve as a will substitute. Because these trusts are so common, the application of the paragraph (xx) subtraction to the income of such a trust is an important practical question.

In Revenue Ruling 19-2012-02, the Department of Revenue describes two methods taxpayers can use to report qualifying revocable trust income in order to take advantage of the paragraph (xx) subtraction. First, if (as is usually the case) the trust is treated as owned by only one person, the grantor can ignore the existence of the trust and report the trust income as if it were received directly by the grantor. ${ }^{99}$ For example, if rental real estate is held by the revocable trust, the rental income can be reported on Schedule E, thereby qualifying for the paragraph (xx) subtraction. This is the easiest method and probably the method currently used by most taxpayers. Alternatively, the trustee can file a

\footnotetext{
93. Kan. Rev. Rul. 19-2012-02, at 3.

94. Id. at 3-4.

95. QUESTIONS AND ANSWERS REGARDING HB 2117, supra note 54, at 3.

96. I.R.C. § 671.

97. See id. §§ 671-672.

98. Id. $\S 676$.

99. See Treas. Reg. § 1.671-4(b)(2)(ii) (as amended in 2006).
} 
Form 1041, the income tax return for trusts and estates, attaching a "separate statement" itemizing the trust income. ${ }^{100}$ Revenue Ruling 192012-02 provides that the grantor can then allocate the income items to Schedule E and other return locations in accord with the instructions for Schedule K-1 for trusts. ${ }^{101}$

Regardless of the reporting method used, the only income qualifying for the paragraph (xx) subtraction is income that is ultimately reported on Schedules C, E, or F. As explained below, the Department of Revenue has ruled that, as a general matter, interest, dividends, and capital gain cannot qualify for the paragraph (xx) subtraction.

\section{vii. Estates}

The principles applicable to complex trusts also govern estates. ${ }^{102}$ As indicated above, to take advantage of the paragraph (xx) subtraction, it will be necessary to distribute estate income currently. Executors will want to take this into account in determining the timing of distributions. Executors should also note the Department of Revenue's position that interest, dividends, and capital gain generally cannot qualify for the paragraph (xx) subtraction.

\section{viii.Interest, Dividends, and Capital Gain}

Except in limited circumstances, the exemption for income from partnerships, S corporations, estates, and trusts does not apply to interest, dividends, and capital gain income generated by these entities. ${ }^{103}$ The reasoning behind this limitation is rather technical. Part (2) of paragraph (xx) states that income from the listed entities qualifies for the paragraph (xx) subtraction only if the income is "reported from schedule $\mathrm{E}$ and on line 17 of the taxpayer's form 1040 federal individual income tax return."104 In other words, taxpayers must meet three requirements to qualify for the paragraph (xx) subtraction:

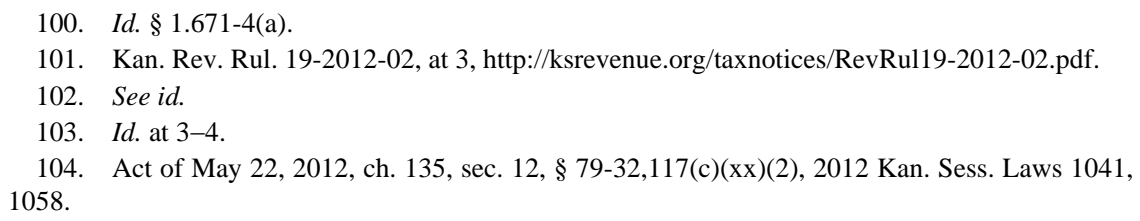


(1) The income must be earned by a partnership, S corporation, trust, or estate;

(2) The income must be reported by the partner, shareholder, or beneficiary on Schedule E of Form 1040; and

(3) The income must be reported by the partner, shareholder, or beneficiary on line 17 of Form 1040.

The Department of Revenue takes the position that items must be "properly reported" on Schedule E to qualify. ${ }^{106}$ The taxpayer must follow the specific directions found in the relevant Schedule K-1s and accompanying instructions, which dictate how pass through entities are to report income and loss to their investors and beneficiaries. ${ }^{107}$ The paragraph (xx) subtraction is available only if the relevant Schedule K-1s and accompanying instructions dictate entry of the income item on Schedule E.

The Schedule K-1s for partnerships, S corporations, trusts, and estates all require that interest and dividends be reported on lines 8 and 9 of Form 1040, ${ }^{108}$ not on Schedule E. Likewise the Schedule K-1s for partnership, S corporations, trusts, and estates are consistent in requiring that both short-term and long-term capital gain be reported on Schedule $\mathrm{D},{ }^{109}$ not on Schedule E. Therefore, it is the Department's position that, in general, interest, dividends, and capital gain earned by a partnership, $\mathrm{S}$ corporation, trust or estate, cannot qualify for the paragraph (xx) subtraction. ${ }^{110}$ There is one important exception. If a partnership or S corporation is in the business of lending, the interest income derived

\footnotetext{
105. See id.

106. Kan. Rev. Rul. 19-2012-02, at 2.

107. Id.

108. Internal ReVenue Serv., Schedule K-1 (Form 1065): PARTNER’s Share OF INCOME, DEDUCTIONS, CREDITS, ETC. 2 (2011), http://www.irs.gov/pub/irs-pdf/f1065sk1.pdf [hereinafter SCHEdUle K-1 (Form 1065)]; InTERnAl REVENUE SERV., SCHEdUle K-1 (Form 1120S): SHAREHOLDER'S SHARE OF INCOME, DEDUCTIONS, CREDITS, ETC. 2 (2011), http://www.irs.gov/ pub/irs-pdf/f1120ssk.pdf [hereinafter SCHEDULE K-1 (FORM 1120S)]; INTERNAL REVENUE SERV., SCHEdule K-1 (Form 1041): Beneficiary's Share of InCOME, Deductions, Credits, ETC. 2 (2011), http://www.irs.gov/pub/irs-pdf/f1041sk1.pdf [hereinafter SCHEDULE K-1 (FORM 1041)]; see also INSTRUCTIONS FOR SCHEDULE K-1, supra note 72, at 7.

109. SCHEDUlE K-1 (Form 1065), supra note 108, at 2; SCHEDULE K-1 (FORM 1120S), supra note 108, at 2; SCHEDULE K-1 (FORM 1041), supra note 108, at 2; see also INSTRUCTIONS FOR SCHEDULE K-1, supra note 72, at 7.

110. Kan. Rev. Rul. 19-2012-02, at 3-4.
} 
from the business can be reported on Schedule E and qualify for the paragraph (xx) subtraction. ${ }^{111}$

\section{ix. Income from Dispositions of Certain Business Property}

Further limitations on the exemption for income from partnerships, S corporations, estates, and trusts arise by reason of reporting technicalities included in federal forms and instructions. For instance, the Schedule E instructions provide that casualty or theft gains and losses involving business property must be reported on Form 4684, ${ }^{112}$ not Schedule E. For this reason, gains from casualty or theft transactions involving business property cannot qualify for the paragraph (xx) subtraction. ${ }^{113}$

The Schedule E instructions also provide that sales, exchanges, and involuntary conversions of property used in a trade or business must be reported on Form 4797, ${ }^{114}$ not Schedule E. For this reason the Department of Revenue takes the position that gains from sales, exchanges, and involuntary conversions of property used in a trade or business cannot qualify for the paragraph (xx) subtraction. ${ }^{115}$ This is an important exception. Under the Department's interpretation, gain on a sale of a building or equipment used in a trade or business cannot qualify for the paragraph (xx) subtraction and will be fully taxed by Kansas.

\section{x. Payments from Retirement Plans and IRAs}

The Department of Revenue takes the position that distributions from IRAs and qualified plans cannot qualify for the paragraph ( $\mathrm{xx}$ ) subtraction. ${ }^{116}$ There remain, however, questions as to whether exceptions to this rule may exist.

Major corporations that use traditional defined benefit retirement plans often transfer the plan assets to a "pension trust." If the retiree receives a payment from a pension trust, can the payment qualify for the paragraph (xx) subtraction because the distribution is from a trust? The answer is "no." The problem is that the payment will be accompanied by

\footnotetext{
111. QueStions AND ANSWERS REgARDING HB 2117, supra note 54, at 4-5.

112. INSTRUCTIONS FOR SCHEDULE E, supra note 57, at 1.

113. See Kan. Rev. Rul. 19-2012-02, at 2, 4 (noting that "income must be properly reported on Schedule C, Schedule E, or Schedule F" to qualify for the paragraph (xx) subtraction).

114. INSTRUCTIONS FOR SCHEDULE E, supra note 57, at 1.

115. Kan. Rev. Rul. 19-2012-02, at 4.

116. Id. at $4-5$.
} 
a Form 1099-R, the information return used to report retirement and IRA distributions, ${ }^{117}$ which will direct the recipient to report the payment on lines 15 or 16 of Form 1040. ${ }^{118}$ According to the Department of Revenue, because Schedule $\mathrm{E}$ is not used, the paragraph (xx) subtraction is not available. ${ }^{119}$

Could a retiree obtain the advantages of paragraph (xx) by causing the plan administrator or IRA custodian to transfer the payment to a nongrantor trust created by the retiree? The answer appears to be "no." Under the traditional "assignment of income" doctrine, the income must be attributed to the retiree-the person whose efforts produced the income. $^{120}$ The retiree cannot shift the tax responsibility to another party. ${ }^{121}$

The answer may be different, however, for IRA and qualified plan payments made after the participant retiree's death. A participant may name a trust as the beneficiary of an IRA or qualified plan after the beneficiary's death. ${ }^{122}$ If the IRA or plan makes post-death payments to the trust, which then distributes the payments to the beneficiary of the trust, can the income qualify for the paragraph (xx) subtraction? The Schedule K-1 instructions suggest that the answer is "yes." Schedule K1 for beneficiaries provides that a catchall category of "other portfolio and nonbusiness income" is to be reported on Schedule E. ${ }^{123}$ The Schedule K-1 instructions for a beneficiary filing Form 1040 state that the "Other Portfolio and Nonbusiness Income" category includes "royalties, annuities, and other income that is not subject to the passive activity rules."124 The Department of Revenue may dispute this interpretation. Revenue Ruling 19-2012-02 states the general rule that retirement benefits cannot qualify for the paragraph (xx) subtraction, ${ }^{125}$

117. Internal REVEnUe SERV., 2012 Instructions FOR FORMS 1099-R AND 5498, at 1 (2012), http://www.irs.gov/pub/irs-pdf/i1099r.pdf.

118. Kan. Rev. Rul. 19-2012-02, at 4.

119. See id.

120. See Lucas v. Earl, 281 U.S. 111, 114-15 (1930) (holding that the income tax cannot "be escaped by anticipatory arrangements and contracts however skillfully devised to prevent the [income] when paid from vesting even for a second in the man who earned it”).

121. See id.

122. See Treas. Reg. § 1.401(a)(9)-4, Q\&A 5 (as amended in 2004); id. § 1.408-8, Q\&A 1 (noting that IRAs are subject to the rules in $\S 1.401(\mathrm{a})(9)$ ).

123. SCHEDULE K-1 (FORM 1041), supra note 108, at 2.

124. InTERNAL REVENUE SERV., 2011 InStRUCTIONS FOR SCHEDUle K-1 (FoRM 1041) FOR A BENEFICIARY FILING FORM 1040, at 1 (2012), http://www.irs.gov/pub/irs-pdf/i1041sk1.pdf (emphasis added).

125. Kan. Rev. Rul. 19-2012-02, at 4-5, http://ksrevenue.org/taxnotices/RevRul19-2012-02.pdf. 
but the Ruling does not specifically address the treatment of payments distributed by a trust that has been named as the a post-death beneficiary of an IRA or retirement plan.

To the extent that retirement income cannot qualify for the paragraph (xx) subtraction, the tax advantages of diverting earnings to a qualified plan or IRA are somewhat reduced, at least for Kansas tax purposes. For example, assume that Albert is a solo practitioner who earns $\$ 100,000$, which he reports on Schedule C. The entirety of this amount will qualify for the paragraph (xx) subtraction and will be exempt from Kansas income tax. If Albert diverts $\$ 10,000$ of his earnings to a qualified plan, he will gain no tax advantage for Kansas income tax purposes because, as explained in Part II.A.5.b, below, Albert must add the qualified retirement plan contribution back to Kansas AGI to prevent him from offsetting income that is not exempt from Kansas income tax. When Albert later retires and receives his $\$ 10,000$ from the qualified plan, the $\$ 10,000$ will not qualify for the paragraph (xx) subtraction and will be taxed by Kansas. In effect, by diverting $\$ 10,000$ to a qualified plan, Albert will have ultimately subjected that amount to Kansas tax. Albert would need to balance the relatively nonadvantageous Kansas tax results against the federal income tax benefits of the qualified plan or IRA contribution, which are unaffected.

\section{c. Category (3): Farm Income}

The final category of income that qualifies for a paragraph (xx) subtraction is "net farm profit" as reported on Schedule F of Form $1040 .{ }^{126}$ Net farm income is distinct from "farm rental" income, which is exempt under part (2) of the paragraph (xx) subtraction. ${ }^{127}$

If the taxpayer is the only member of an LLC that has not elected to be taxed as a corporation, the LLC is ignored for federal tax purposes. ${ }^{128}$ Therefore, an owner of such a single-member LLC engaged in farming may use Schedule F and qualify for the paragraph (xx) subtraction. ${ }^{129}$

As noted above, the Department of Revenue takes the position that, generally, interest, dividends, and capital gain income cannot qualify for

126. Act of May 22, 2012, ch. 135, sec. 12, § 79-32,117(c)(xx)(3), 2012 Kan. Sess. Laws 1041, 1058-59.

127. See id. § 79-32,117(c)(xx), at 1058-59.

128. Treas. Reg. § 301.7701-3(b)(1)(ii) (as amended in 2006).

129. Notice 12-11, supra note 40 , at 5 . 
the subtraction. ${ }^{130}$ Similarly, because the Schedule F instructions provide that casualty or theft gains and losses involving business property must be reported on Form 4684, ${ }^{131}$ not Schedule F, these gains also do not qualify. ${ }^{132}$

More importantly, under the Department's interpretation, gain from the sale of farmland cannot qualify for the paragraph (xx) subtraction and will be fully taxed by Kansas. The Department bases its interpretation on the Schedule F instructions, which provide that sales, exchanges, and involuntary conversions of property used in the trade or business must be reported on Form 4797, ${ }^{133}$ not Schedule F. Because the Schedule F instructions likewise state that Form 4797 must be used "to report sales of livestock held for draft, breeding, sport, or dairy purposes," ${ }^{\text {"134 it }}$ appears that gain on a sale of such livestock will not qualify for the paragraph (xx) subtraction.

\section{d. Exemptions are Cumulative}

The exemption categories are cumulative, and a taxpayer can take advantage of multiple subtractions simultaneously. ${ }^{135}$ For example, assume that Laura is a partner in a Johnson County law firm. In addition, she receives income from farm property in Thomas County inherited from her mother. Laura's share of partnership income qualifies for the subtraction in paragraph (2), and her farm income qualifies for the subtraction in paragraph (3). As a result, her Kansas AGI from both sources will be zero.

\section{e. No Size Limit}

Paragraph (xx) has been promoted as a vehicle for encouraging small business. The Governor's press release that accompanied the signing of HB 2117 states that HB 2117 "eliminates state income taxes on more than 191,000 small business owners."136 However, there is no size

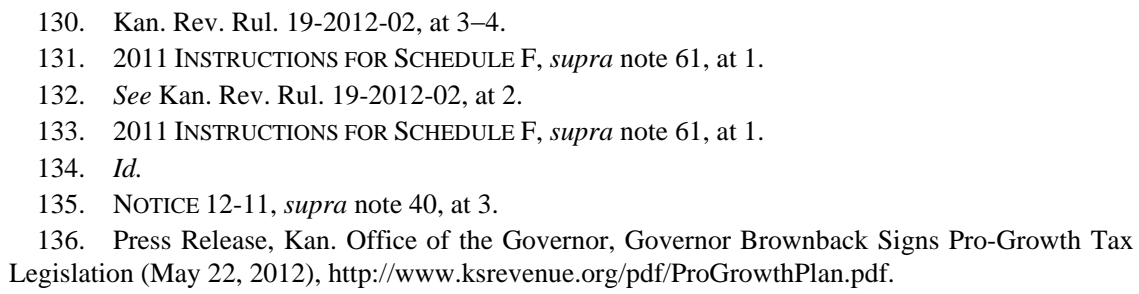


limitation in the statute. The income of any enterprise, regardless of size, can be effectively sheltered from Kansas tax if the enterprise operates as a sole proprietorship, partnership, S corporation, or LLC.

\section{f. Nonresidents}

HB 2117 applies to both residents and nonresidents of Kansas. ${ }^{137}$ For example, a nonresident shareholder in a Kansas S corporation can take full advantage of the paragraph (xx) subtraction in determining her Kansas tax liability. ${ }^{138}$

\section{Additions to Federal AGI}

As noted above, Kansas AGI consists of federal AGI, as adjusted pursuant to section 79-32,117 of the Kansas Statutes. The adjustments include both subtractions and additions. The preceding Part II.A.4 describes new subtractions that will have the effect of freeing from Kansas tax (1) income of independent contractors, (2) income from partnerships, S corporations, estate, and trusts, and (3) farm income. Because these categories of income will no longer be taxed, the Kansas Legislature concluded that taxpayers should not be permitted to offset losses or take deductions attributable to such activities against income from taxable sources, such as salary. These anti-sheltering limitations are discussed below.

\section{a. Losses}

Paragraph (xix) of HB 2117 limits the deduction of losses from activities that are otherwise exempt from Kansas income tax. ${ }^{139}$

Example: Ann is a lawyer employed by a corporation. Also, she is a $25 \%$ partner in a manufacturing partnership consisting of four partners. The partnership earns $\$ 200,000$ in 2013. The deduction provided by new paragraph (xx) of section 79-32,117(c) shelters from Kansas tax the entirety of the $\$ 50,000$ of partnership income allocable to Ann.

\footnotetext{
137. QUESTIONS AND ANSWERS REgARDING HB 2117, supra note 54, at 2.

138. See id.

139. See Act of May 22, 2012, ch. 135, sec. 12, § 79-32,117(b)(xix), 2012 Kan. Sess. Laws
} 1041, 1055. 
In 2014 Ann receives a salary of $\$ 80,000$ from the corporation. The partnership, however, incurs a loss of $\$ 100,000$, and Ann's share of this loss is $\$ 25,000$. The $\$ 25,000$ loss lowers Ann's federal AGI to $\$ 55,000 .{ }^{140}$ Under current law, Ann's initial Kansas AGI is therefore $\$ 55,000 .{ }^{141}$ New paragraph (xix) of HB 2117 requires that Ann increase her Kansas AGI by $\$ 25,000$ to $\$ 80,000$. This prevents Ann from, in effect, deducting her partnership loss against her salary.

This rule applies to losses sustained in any of the three subdivisions of new paragraph (xx): (1) sole proprietor income, (2) income from the sources or activities described in part (2), and (3) farm income. ${ }^{142}$

\section{b. Certain Items Deductible Under Federal Law}

Similar sheltering opportunities arise in the case of certain deductions. Some items are deductible under federal law, but the deduction is not shown on Schedule C, E, or F. Instead, the deduction is shown on a line of Form 1040. These include: (1) one-half of selfemployment taxes, ${ }^{143}$ (2) contributions to retirement plans by selfemployed taxpayers, ${ }^{144}$ (3) purchases of health insurance by selfemployed taxpayers, ${ }^{145}$ and (4) the deduction for domestic production activities. ${ }^{146}$ To prevent a self-employed person or partner from deducting these items against income not covered by the paragraph (xx) subtraction, such as salary, HB 2117 provides that the amount of any of these deductions must be added to Kansas AGI. ${ }^{147}$

Example: Joe receives a salary of $\$ 100,000$ from an employer who does not provide health insurance. Joe also moonlights as an auctioneer and reports his auction business income on Schedule $\mathrm{C}$ as an independent contractor. The auction business produces net earnings of $\$ 50,000$. The $\$ 50,000$ of auction income qualifies for the paragraph (xx) subtraction.

\footnotetext{
140. See I.R.C. § 702(a) (2006).

141. KAN. STAT. ANN. § 79-32,117(a) (Supp. 2011).

142. Sec. 12, § 79-32,117(b)(xix), 2012 Kan. Sess. Laws at 1055.

143. I.R.C. § 164(f) (Supp. IV 2007-2011); see also INTERNAL REVENUE SERV., Form 1040: U.S. INDIVIDUAL INCOME TAX RETURN 1 (2011), http://www.irs.gov/pub/irs-pdf/f1040.pdf [hereinafter FORM 1040] (line 27).

144. I.R.C. § 62(a)(6) (2006); see also FORM 1040, supra note 143, at 1 (line 28).

145. I.R.C. § 162(l) (Supp. IV 2007-2011); see also FoRM 1040, supra note 143, at 1 (line 29).

146. I.R.C. § 199; see also FoRM 1040, supra note 143, at 1 (line 35).

147. Sec. 12, § 79-32,117(b)(xix), 2012 Kan. Sess. Laws at 1055. HB 2117 adds subparagraphs (xx), (xxi), (xxii), and (xxiii) to section 79-32,117(b).
} 
Joe spends $\$ 6,000$ on health insurance. As a self-employed person, Joe can deduct the $\$ 6,000$ spent on health insurance under IRC $\$ 162(l)$. The $\$ 6,000$, however, is not deducted on Schedule C, but on line 29 of Form 1040. Therefore, Joe's Schedule C contribution to his federal AGI will be $\$ 50,000$. Joe's federal AGI is $\$ 100,000$ plus $\$ 50,000$ less $\$ 6,000$, or $\$ 144,000$.

Joe's Kansas AGI starts at the federal AGI of $\$ 144,000$. Under new paragraph (xx) of section 79-32,117(c), Joe can subtract the Schedule C income of $\$ 50,000$, reducing his Kansas AGI to $\$ 94,000$. If the computation ended here, Joe could in effect deduct the $\$ 6,000$ health insurance expense against his salary income. Because Joe is not taxed by Kansas on his income from the auction business, he should not be permitted to set off a deduction related to the auction business (the insurance premiums) against his income from taxable sources, such as salary. To prevent this sort of sheltering, new subparagraph (xxii) of section 79-32,117(b) provides that Joe must add back to his Kansas AGI the $\$ 6,000$ spent for health insurance. Joe's AGI is therefore $\$ 94,000$ plus $\$ 6,000$, or $\$ 100,000$. As a result, Joe is taxed on the entirety of his salary income, as the Legislature intended.

The same approach applies to each of the other three expenditures that are not reported on Schedule C.

In the case of retirement contributions, section 12 of HB 2117 requires an addition to Kansas AGI only if the contribution is to a selfemployed SEP, SIMPLE, or qualified plan. ${ }^{148}$ No addition is required for an ordinary IRA contribution. ${ }^{149}$

\section{B. Taxation of C Corporation Income}

HB 2117 makes no change in the taxation of C corporations, i.e., corporations that have not made a subchapter $\mathrm{S}$ election. The income of C corporations will continue to be taxed at the current rates: $4 \%$ on the first $\$ 50,000$ of taxable income and $7 \%$ on all taxable income over $\$ 50,000$. $^{150}$

Under current law the Kansas taxable income of a C corporation is determined by applying the same adjustments as those available to an individual under section 79-32,117(b) and (c). ${ }^{151}$ HB 2117, however, confirms that the paragraph $(\mathrm{xx})$ subtraction does not apply to $\mathrm{C}$

\footnotetext{
148. Id. § 79-32,117(b)(xxi), 2012 Kan. Sess. Laws at 1055.

149. QUESTIONS AND ANSWERS REGARDING HB 2117, supra note 54, at 2.

150. KAN. STAT. ANN. § 79-32,110(c) (Supp. 2011).

151. Id. § 79-32,138.
} 
corporations. ${ }^{152}$ As a result, C corporations will continue to be taxed on income received from partnerships and from limited liability companies that are taxed as partnerships. ${ }^{153}$

Beginning in 2013, "certain credits will be available only to corporations that are subject to the Kansas corporate income tax, i.e., C corporations." $^{\text {"154 }}$ These credits ${ }^{155}$ may be applied only against C

152. Sec. 15, § 79-32,128(b), 2012 Kan. Sess. Laws at 1060; see also KAN. DeP’T OF ReVEnUE, Notice 12-09: ReCEnT ChANGes Do Not AfFeCt CoRporate InCOME TAX 1 (2012), http://www.ksrevenue.org/taxnotices/notice12-09.pdf [hereinafter NOTICE 12-09].

153. See id. (noting "the modifications used for computing the Kansas corporate income tax will not change").

154. KAN. DeP'T OF REVENUE, NOTICE 12-05: EliminATION OF CERTAIN INCOME TAX CREDITS FOR INDIVIDUALS, PARTNERSHIPS, S CORPORATIONS, AND LIMITED LIABILITY COMPANIES: CARRY OVER OF UNUSED CREDITS 1 (2012), http://www.ksrevenue.org/taxnotices/notice12-05.pdf [hereinafter NOTICE 12-05].

155. The credits available only to $\mathrm{C}$ corporations are as follows.

(1) “Credit for financial support provided to persons eligible to receive aid to families with dependent children under agreement with SRS” per sections 39-7,132 and 7932,200. Id. (citing Sec. 1, § 39-7132, 2012 Kan. Sess. Laws at 1041; Sec. 22, § 7932,200, 2012 Kan. Sess. Laws at 1068-69).

(2) "Credit for employers providing health insurance or care, or contributions to health savings accounts” per section 40-2246. Id. (citing Sec. 2, § 40-2246, 2012 Kan. Sess. Laws at 1041-42).

(3) “Credit for contributions to an individual development account” per section 65-7107. Id. (citing Sec. 3, § 65-7107, 2012 Kan. Sess. Laws at 1042-43).

(4) “Credit for purchase of liability insurance by an agritourism operator” per section 7450,173. Id. (citing Sec. 3, § 74-50,173, 2012 Kan. Sess. Laws 1043-44).

(5) “Credit for contributions to community-based organizations" per section 74-50,208.

Id. (citing Sec. 5, § 74-50,208, 2012 Kan. Sess. Laws at 1044-45).

(6) “Credit for investment in Kansas Venture Capital, Inc.” per section 74-8206. Id. (citing Sec. 6, § 74-8206, 2012 Kan. Sess. Laws at 1045).

(7) “Credit for investment in certified Kansas venture capital companies” per section 748304. Id. (citing Sec. 7, § 74-8304, 2012 Kan. Sess. Laws at 1045-46).

(8) "Credit for investment in a technology-based venture capital fund" per section 748316. Id. at 2 (citing Sec. 8, § 74-8316, 2012 Kan. Sess. Laws at 1047-48).

(9) “Credit for investment in a certified local seed capital pool” per section 74-8401. Id. (citing Sec. 9, § 74-8401, 2012 Kan. Sess. Laws at 1049-50).

(10)“Credit for expenditures to provide disabled access” per section 79-32,177. Id. (citing Sec. 19, § 79-32,177, 2012 Kan. Sess. Laws at 1066).

(11)“Credit for research and development expenditures” per section 79-32,182b. Id. (citing Sec. 20, § 79-32,182b, 2012 Kan. Sess. Laws at 1066-67).

(12)“Credit for provision of child care services or facilities” per section 79-32,190. Id. (citing Sec. 21, § 79-32,190, 2012 Kan. Sess. Laws at 1067-68).

(13)“Credit for expenditures for a qualified alternative-fueled motor vehicle or alternative-fuel fueling station” per section 79-32,201. Id. (citing Sec. 23, § 79-32,301, 2012 Kan. Sess. Laws at 1069-71).

(14)“Credit for required improvements to a qualified swine facility” per section 7932,204. Id. (citing Sec. 24, § 79-32,204, 2012 Kan. Sess. Laws at 1071-72).

(15)“Credit for plugging an abandoned oil or gas well” per section 79-32,207. Id. (citing 
corporation income tax liability and will not be available to individuals, partnerships, S corporations, or to LLCs that are treated as partnerships for federal income tax purposes. ${ }^{156}$ Because these entities will not pay current tax on their earnings, there is no tax liability to offset the credits against.

Further limitations also help ensure that taxpayers taking advantage of the exemptions in paragraph (xx) cannot utilize tax benefits arising from these exempt sources of income to shelter other income. For example, the Promoting Employment Across Kansas Act ${ }^{157}$ provides that an employer may retain a portion of withheld Kansas income taxes if the employer locates, relocates, or expands a qualified business in Kansas. ${ }^{158}$ There are strict eligibility requirements regarding material participation and other factors. ${ }^{159}$ In addition, section 79-32,266 provides a 95\% credit against the tax liability of a Kansas resident who owns a business relocated to Kansas and who qualifies under the Promoting Employment Across Kansas Act. ${ }^{160}$ Under section 38(c) of HB 2117, the 95\% credit is not available if the owner takes advantage of the paragraph (xx) subtraction discussed above, which may eliminate tax liability as to the earnings of the business. ${ }^{161}$ The credit remains available to $\mathrm{C}$ corporations.

For similar reasons, HB 2117 provides that the additional expense deduction for purchases of certain business property provided by section 79-32,143a will be available only to C corporations. ${ }^{162}$ Furthermore, beginning in 2013, the net operating loss deduction will not be available

Sec. 25, § 79-32,207, 2012 Kan. Sess. Laws at 1072-73).

(16)“Credit for certain property taxes imposed on telecommunications companies” per section 79-32,210. Id. (citing Sec. 26, § 79-32,210, 2012 Kan. Sess. Laws at 1073-74).

(17)“Credit for income attributable to the retirement of indebtedness authorized by a single city port authority” per section 79-32,212. Id. (citing Sec. 27, § 79-32,212, 2012 Kan. Sess. Laws at 1074).

(18)“Credit for expenditures to bring a refinery into compliance with environmental standards or requirements” per section 79-32,222. Id. (citing Sec. 28, § 79-32,222, 2012 Kan. Sess. Laws at 1074-75).

156. See id. at 1.

157. KAN. STAT. ANN. §§ 74-50,210 to -50,300 (Supp. 2011).

158. Id. § 74-50,212.

159. See id. (providing that qualified companies must engage in certain activities to receive the benefits of the Act).

160. Id. § 79-32,266(a).

161. Act of May 22, 2012, ch. 135, sec. 38, § 79-32,266(c), 2012 Kan. Sess. Laws 1041, 1088. Actually, section 38(c) refers to paragraph (xxi), not (xx). However, there is no paragraph (xxi), and it appears that the Legislature intended to refer to paragraph (xx), which was numbered (xxi) at an earlier point in the legislative process.

162. Id. sec. 18, § 79-143a(h), 2012 Kan. Sess. Laws at 1065. 
to individuals, partnerships, S corporations, or to LLCs taxed as partnerships. ${ }^{163}$ As a result, only C corporations can carry forward net operating losses from pre-2013 years. ${ }^{164}$ Individuals and all other entities not taxed as $\mathrm{C}$ corporations will permanently lose the benefit of carry forwards from pre-2013 years. ${ }^{165}$

Section 79-32,117(b)(iii) currently provides that a net operating loss deduction claimed on the federal return must be added back in computing Kansas AGI. ${ }^{166}$ HB 2117 did not amend this provision. Therefore, the add-back rule will continue for years after 2012. ${ }^{167}$

HB 2117 also addresses the treatment of unused pre-2013 nonrefundable credits available to individuals, partnerships, and S corporations, and to LLCs taxed as partnerships. ${ }^{168}$ Such credits may be claimed in 2013 and later years, subject to the limitations applicable at the time the credit was earned. ${ }^{169}$

\section{Other Taxes}

The following is a list of other tax provisions affected by HB 2117. Several of these provisions are discussed in more detail in Part V.

\section{Sales Tax}

HB 2117 makes no change in the scheduled July 1, 2013, reduction in the state sales tax rate from $6.3 \%$ to $5.7 \% .{ }^{170}$

\section{Homestead Property Tax Refunds}

Kansas law currently provides a partial refund of a portion of the property taxes paid by homeowners who are elderly, disabled, or have low incomes and dependents. ${ }^{171}$ The refund is currently available to

163. See id. sec. 17, § 79-32,143(g), 2012 Kan. Sess. Laws at 1063.

164. Id.; see also KAN. DeP'T OF REVEnUE, NotiCE 12-08: Net OperATING Losses 1 (2012), http://www.ksrevenue.org/taxnotices/notice12-08.pdf [hereinafter NOTICE 12-08].

165. See Notice 12-08, supra note 164, at 1; QUESTIONS AND ANSWERS REGARDING HB 2117, supra note 54 , at 1 .

166. KAN. STAT. ANN § 79-32,117(b)(iii) (Supp. 2011).

167. NOTICE $12-08$, supra note 164 , at 1 .

168. Sec. 36, 2012 Kan. Sess. Laws at 1086.

169. See NotiCE 12-05, supra note 154, at 3.

170. KAN. STAT. ANN. § 79-3603.

171. Id. $\S \S 79-4501$ to -4531 . 
renters as well, and $15 \%$ of the rent is treated as a deemed payment of property tax. ${ }^{172}$ HB 2117 limits the refund to owners; renters no longer qualify. ${ }^{173}$

\section{Food Sales Tax Refunds}

Kansas law currently "provides a refund of sales tax paid on food by low-income individuals who are elderly, disabled, or have young dependents living with them." ${ }^{174}$ HB 2117 repeals this refund. ${ }^{175}$

\section{Severance Tax}

Current law provides an exemption from the section 79-4217(a) severance tax for the first twenty-four months of production of oil or gas from a "pool.,"176 For this purpose, " "pool' means an underground accumulation of oil or gas in a single and separate natural reservoir characterized by a single pressure system so that production from one part of the pool affects the reservoir pressure throughout its extent."177

With the exception of certain oil pools described in the following paragraph, HB 2117 limits the twenty-four-month exemption to pools from which oil or gas was first produced prior to July 1, 2012. ${ }^{178}$

In the case of oil pools from which oil is first produced after July 1, 2012, the exemption remains available, but only if production does not exceed fifty barrels per day as certified by the Kansas Corporation Commission. ${ }^{179}$ The Department of Revenue interprets the production limit to be "50 barrels per well in the pool, per day."

Notice 12-16 sets forth the Department's position on severance tax return due dates. The Notice indicates that "the Department has occasionally granted taxpayers what amounted to a standing extension of

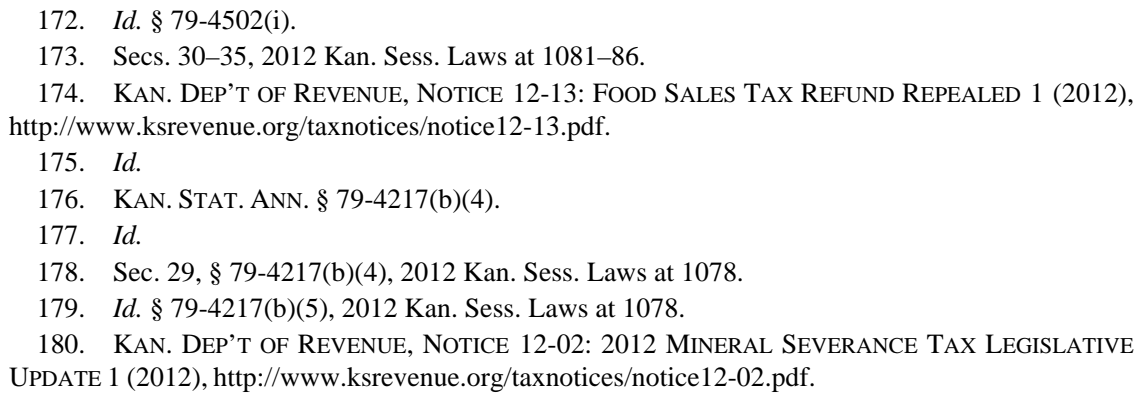


time to file their mineral severance tax returns.”181 The Notice states that "[t]his practice has been discontinued and no such extensions will be granted in the future."182

\section{PART THREE: EXPOSURE TO GAMING}

As explained in Part II.A.4, HB 2117 entirely exempts from Kansas income tax many categories of income. This will surely entice some taxpayers to try to bring their business and investment activities within one of the exempt categories. To the extent these efforts reflect a change in form and not substance, they may be viewed as efforts to "game" the new system. Both the Department of Revenue and the Legislature should be alert to such efforts and should enact legislation or interpretations preventing inappropriate gaming. This Part lists only a few of the most obvious gaming possibilities. Without doubt, time will reveal others.

\section{A. Transforming Employees into Independent Contractors}

Some employees, learning of the tax exemption available to independent contractors, will seek to attain that status, and many employers may receive requests of this kind.

Any employee seeking to change to independent contractor status should be reminded of the obligations she will assume. First, as an independent contractor, the service provider will be responsible for the entire employment tax, rather than the one-half she paid as an employee. Ignoring the temporary reduction in the Social Security tax rate in effect during 2011 and 2012, an employee pays Social Security and Medicare tax of $7.65 \%$ on wages up to the wage base $\left(\$ 113,700\right.$ in $\left.2013^{183}\right)$ plus Medicare tax of $1.45 \%$ on all wages over the wage base. ${ }^{184}$ The employer is required to withhold these amounts from the employee's pay. ${ }^{185}$ The employer pays an equivalent amount of behalf of the

181. Kan. Dep’t of Revenue, Notice 12-16: Mineral Severance Tax Return Due Date 2 (2012), http://www.ksrevenue.org/taxnotices/notice12-16.pdf.

182. Id.

183. See Automatic Determinations in Recent Years, SoCIAL SECURITY ADMIN., http://www.ssa. gov/oact/cola/autoAdj.html (last modified Oct. 16, 2012).

184. See I.R.C. $\S 3101$ (2006). Beginning in 2013, an additional Medicare tax of $0.9 \%$ is imposed on wages in excess of $\$ 250,000$ (joint return) or $\$ 200,000$ (single return). Id. $\S 3101(\mathrm{~b})$ (West 2012).

185. Id. § 3102(a) (2006). 
employee. ${ }^{186}$ If the service provider becomes an independent contractor, she will be responsible for payment of the entire employment tax (15.3\% up to the wage base and $2.90 \%$ over the wage base) ${ }^{187}$ In addition, the employer will no longer withhold federal income tax, and the service provider will be exposed to the penalty for underpayment of estimated tax if she does not make the appropriate periodic estimated tax payments. ${ }^{188}$

Any change to independent contractor status also creates significant risk for the employer. Under federal law, an employer is required to withhold employment taxes and income taxes from an employee's compensation and must pay to the United States the employer's one-half share of employment taxes. ${ }^{189}$ If the employer mischaracterizes the service provider's status as an independent contractor rather than an employee, the employer risks serious financial penalties for noncompliance with the employer's withholding obligations. ${ }^{190}$

The risk of mischaracterization is great because the status of a worker is determined based on the surrounding facts and circumstances, not by the name given to the relationship. If the facts and circumstances indicate that the service provider is an employee, the employer's withholding and payment obligations are triggered, without regard to the label placed on the relationship by the parties.

The Internal Revenue Service has issued a list of twenty factors that it uses to make this determination. ${ }^{191}$ Under this analysis, a worker must be treated as an employee if a substantial number of the following factors are present:

(1) The worker must comply with instructions.

(2) The business trains the worker.

(3) The worker's services are integrated into the business.

(4) The worker provides the services personally.

(5) The business hires, supervises, and pays the worker's assistants.

(6) The business and the worker have a continuing relationship.

(7) The business establishes set hours of work.

(8) The worker must work full time.

186. Id. §3111(a)-(b).

187. Id. § 1401. Beginning in 2013 an additional Medicare tax of $0.9 \%$ is imposed on selfemployment earnings in excess of $\$ 250,000$ (joint return) or $\$ 200,000$ (single return). Id. $\S$ 1401(b)(2) (West 2012).

188. Id. § 6654 (Supp. IV 2007-2011).

189. Id. §§ 3102(a), 3402(a) (2006).

190. See id $\S 7202$ (describing penalties for failing to collect or pay required tax).

191. Rev. Rul. 87-41, 1987-1 C.B. 296. 
(9) The work is performed on the business premises.

(10) The business prescribes a sequence for the worker's services.

(11) The worker must submit oral or written reports.

(12) Pay is by the hour, week, or month.

(13) The business pays travel and other expenses of the employee.

(14) The business furnishes tools and materials.

(15) The worker does not invest in facilities or equipment.

(16) The worker cannot realize a profit or loss.

(17) The worker does not work for more than one business at a time.

(18) The worker's services are not available to the general public.

(19) The business has the right to discharge the worker.

(20) The worker has the right to terminate the relationship. ${ }^{192}$

Any employer who is asked to change a worker's status to that of independent contractor should examine the relationship carefully to assure that the relationship does not incorporate a substantial number of these elements.

It is doubtful that HB 2117 could be amended in a way that would effectively prevent this kind of gaming. However, both the increased federal financial burden imposed on an independent contractor and the penalties to which an employer could be subjected should greatly diminish the scope of avoidance.

\section{B. Partners in Name Only}

The exemption for income from a partnership may encourage some employees of partnerships to seek out some form of partner status in circumstances in which there is little or no change in the employee's conditions of employment. A good example is an associate who is currently an employee of a law firm organized as a partnership. The partners could create a new "junior partner" category that would entail fixed compensation, no voting rights, and no job security. From a practical perspective, there might be no substantive change in the junior partner's conditions of employment. Yet the partner's share of the partnership income would qualify for the paragraph (xx) subtraction and be exempt from Kansas income tax.

As explained above in connection with independent contractor status, the junior partner would have to pay the entirety of the employment taxes and would be exposed to estimated tax underpayment penalties. These factors present a deterrent to most efforts to exploit this opportunity, 
although some professional firms may negotiate a sharing of any potential tax savings and restructure relationships accordingly.

\section{Channeling Service Income Through a Partnership or LLC}

Efforts to exploit the new exemptions by channeling service income through a partnership or LLC also presents an opportunity to game the new law. Assume, for example, that a bank wants to hire Alan as its Technology Manager. Alan has the characteristics of an employee as described above: the bank will provide the place of work and materials, and Alan will perform the tasks to which he is assigned by bank management. Alan asks that, instead of structuring his position as an employee, the bank contract for the desired services with Tech LLC, an LLC owned by Alan and his minor son.

For federal income tax purposes Alan will be taxed as a partner. If there is no significant capital investment, the family partnership rules of IRC $\S 704(e)(2)$ will require that all the income be allocated to Alan for tax purposes. The character of the income received by the LLC will flow through to Alan and he will be responsible for payment of federal selfemployment taxes.

For federal income tax purposes, the income of the LLC will be reported as ordinary business income and will eventually be reported on Schedule E of Alan's Form 1040. ${ }^{193}$ As a result, it appears that the income will qualify for the paragraph (xx) subtraction and be effectively exempt from Kansas tax. ${ }^{194}$ That remains true even though, had Alan performed the same services for the bank in his individual capacity, he would have been treated as an employee.

Channeling service income through a partnership or other entity that qualifies for the paragraph (xx) subtraction presents what may turn out to be the biggest "loophole" associated with the new legislation. It may also prove to be the most difficult maneuver for the revenue authorities to prevent.

193. SCHEDULE K-1 (FORM 1065), supra note 108, at 2.

194. The income would also be reported on Schedule SE of Alan's Form 1040, but only for purposes of determining Alan's federal self-employment tax obligation. See INTERNAL REVENUE Serv., Dep'T of the Treasury, 2012 Instructions for Schedule SE (Form 1040), SElFEMPLOYMENT TAX SE-4 (2012), http://www.irs.gov/pub/irs-pdf/i1040sse.pdf. 


\section{PART FOUR: UNRESOLVED ISSUES}

Because HB 2117 is novel and makes major changes in Kansas tax law, it should not be surprising that uncertainties exist regarding its interpretation and application.

\section{A. Easy Fixes}

In some cases, the uncertainties arose from poor legislative drafting. For example, section 38 of HB 2117 provides that the relocation or expansion credit provided by section 79-32,226 of the Kansas Statutes is not available to a business that utilizes either of the modifications provided by section 79-32,117(b)(xix) or 79-32,117(c)(xxi). ${ }^{195}$ There is no section 79-32,117(c)(xxi), and it seems certain that the reference to paragraph (xxi) should be to (xx). The 2013 legislature could easily correct this technical error.

Other areas of uncertainty have already been addressed by the Department of Revenue. In fact, the department issued more than twenty interpretations within the first several months after the legislation was signed into law. ${ }^{196}$ Notice 12-07, for instance, addresses the conflict between section 79-32,118, which appears not to allow itemization of deductions, and section 79-32,120, which does allow itemization. ${ }^{197}$ It remains only for the Kansas legislature to either confirm or reject the Department of Revenue's notice stating the Department's view that the legislature intended to allow itemization. If the legislature agrees with the notice, it should eliminate this conflict by repealing section 7932,118 .

Finally, there is the question whether qualified plan and IRA distributions channeled through a trust after the death of the participant can qualify for the paragraph (xx) subtraction, as discussed in Part II.A.4.b.x. The Legislature should resolve this issue.

195. Act of May 22, 2012, ch. 135, sec. 38, § 79-32,266(c), 2012 Kan. Sess. Laws 1041, 1088.

196. See New Tax Notices, Kan. Department Revenue, http://www.ksrevenue.org/newtax notices.html (last visited Nov. 11, 2012).

197. NOTICE 12-07, supra note 20, at 1-2. 


\section{B. Harder Decisions: The Section 37 Partnership and S Corporation Basis Adjustments}

The most pressing concern, and the one that may have the greatest revenue effect, relates to the ambiguous basis adjustment provisions in section 37 of HB 2117. As noted above, paragraph (xx) eliminates tax on partnership and $\mathrm{S}$ corporation income allocated (but not yet distributed) to a partner or shareholder. But what happens when that income is actually distributed? Is the distribution also tax free? What happens when the partner or shareholder sells her interest, with the sale price reflecting undistributed earnings? Will the gain from the sale of the interest remain tax free or will that gain be subject to Kansas income tax?

The answers depend on the basis the partner or shareholder has in her partnership interest or stock. Section 37 of HB 2117 could be interpreted as requiring a basis calculation that would trigger income for Kansas tax purposes when a partnership or $\mathrm{S}$ corporation distributes earnings or when investors sell their interests in these entities at a gain. The explanation below first describes the well-established federal income tax basis rules, followed by a discussion of possible interpretations of section 37. For purposes of simplicity, a partnership is used in exploring these issues. Analogous principles apply to S corporations.

\section{Basis for Federal Income Tax Purposes}

Under Federal law, a partner's basis for her partnership interest increases when the partner contributes cash or property to the partnership $^{198}$ and also increases by the amount of partnership income on which she is taxed. ${ }^{199}$ Because tax has already been paid on the partnership income, the basis increase for earnings is necessary to prevent double taxation of partnership income.

Example: Sallie is a one-third partner in a law firm that rents its offices from a third party and also rents its furniture and equipment. The partners make no investment at the outset; as a result, Sallie has a zero basis when the partnership begins business. In the first year the partnership earns $\$ 210,000$, and Sallie's share is $\$ 70,000$. Sallie is taxed on \$70,000 under IRC § 702. Under IRC § 705(a)(1)(A), Sallie’s basis for her partnership interest is increased by the amount of the earnings on which she is taxed from $\$ 0$ to $\$ 70,000$.

198. I.R.C. § $722(2006)$

199. Id. § 705(a)(1)(A). 
If Sallie sells her interest in the partnership to Tom for $\$ 70,000$, she can apply her basis of $\$ 70,000$ against the amount realized. Consequently, she will have no gain on the sale. ${ }^{200}$ This is the correct result because the federal partnership tax regime is designed to tax partnership earnings only once.

Likewise, if the partnership actually distributes Sallie’s \$70,000 share of the partnership income to her, Sallie will have no taxable income because, on a distribution, Sallie is taxed only on the amount by which the distribution exceeds Sallie's basis. ${ }^{201}$ Because Sallie has a basis of $\$ 70,000$ for her partnership interest, she has no gain on the distribution. Taxing distributions only to the extent that they exceed a partner's basis in her partnership interest also ensures that partnership earnings are taxed only once.

\section{Basis for Kansas Income Tax Purposes}

Section 37(a)(1) of HB 2117 promulgates a special basis rule for Kansas:

For Kansas income tax purposes: (1) The basis of a partner's interest in a partnership formed prior to January 1, 2013, shall be determined by computing the basis as of January 1, 2013, in accordance with section 705 of the federal internal revenue code as in effect on January 1, 2013, and amendments thereto, and making any subsequent adjustments to the partner's interest as provided in section 733 of the federal internal revenue code as in effect on January 1, 2013, and amendments thereto. $^{202}$

Section 37(b)(1) establishes an analogous rule for S corporations. ${ }^{203}$

Section 37(a)(2) and (b)(2) promulgate the same rule for partnerships and S corporations created after 2012. In the case of partnerships, the original basis is determined under IRC $\S 705$, but basis adjustments after that are apparently determined entirely by IRC $\S 733 .{ }^{204}$ In the case of S corporations, the original basis is determined by the entirety of IRC $\S$ 1367, but basis adjustments after that are apparently determined entirely by IRC $\S 1367(a)(2)(A){ }^{205}$

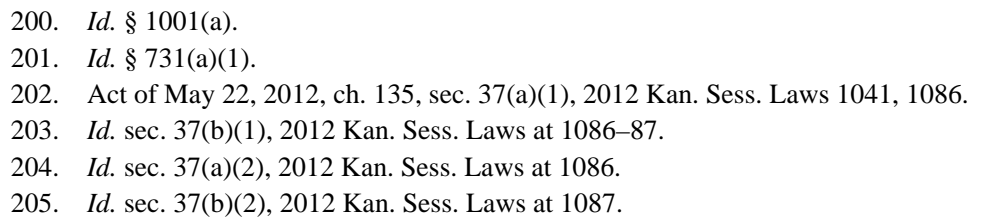


One reading of section 37(a) is that, beginning January 1, 2013, the only adjustments that can be made to the basis of a partnership interest for Kansas income tax purposes are those dictated by IRC $\S 733$, which allows adjustments only for distributions. Crucially, this interpretation would eliminate the IRC $\S$ 705(a)(1)(A) basis increase for partnership earnings and dramatically change the effect of HB 2117 on partnerships.

Example: The facts are the same as in the preceding example. For federal income tax purposes, Sallie has no gain on the sale of her partnership interest for $\$ 70,000$. Likewise, for federal purposes she has no gain if the partnership distributes her $\$ 70,000$ share of the partnership income. For Kansas purposes, however, section 37 prevents any basis increase under IRC $\S 705(a)(1)(A)$ to reflect the $\$ 70,000$ of earnings. Therefore, for Kansas purposes Sallie retains a zero basis in her partnership interest. If she sells her interest for $\$ 70,000$, Sallie recognizes $\$ 70,000$ of taxable gain for Kansas income tax purposes. Likewise, if the partnership distributes $\$ 70,000$ to Sallie, for Kansas purposes, the distribution produces $\$ 70,000$ of taxable gain for Kansas income tax purposes.

This interpretation of section 37 would largely negate the benefits the Legislature apparently intended to confer under the new paragraph (xx) subtraction. Although a partner would not be taxed on her share of partnership income when earned, the partner or shareholder could ultimately be taxed when those earnings are distributed to the partner, or when the partner sells her interest. In other words, the Kansas tax on income earned by a partnership entity would not be eliminated, but would simply be deferred.

In the case of a service partnership, where the partners have little or no basis at the outset, this interpretation would render illusory the benefits of the paragraph (xx) subtraction. If the partner does make a capital investment at the outset of the partnership, with the result that a partner has a basis, the partner would be able to withdraw earnings without tax liability up to the partner's original basis. Withdrawals in excess of the partner's basis, however, would be taxed by Kansas. These same principles would apply to S corporations.

Further problems relating to the basis adjustment also exist. For example, section 37 seems to negate the possibility of a basis increase for further contributions to a partnership under IRC § 721. Likewise, section 37 seems to negate the possibility of a basis increase for further contributions to an S corporation under IRC $\S 1012$. It is even possible that section 37 could be read as preventing any basis increase for a partnership or $\mathrm{S}$ corporation interest at the death of the owner pursuant to 
IRC $\S 1014$. Finally, if the effect of section 37 is to adjust basis differently for Kansas purposes, it will be necessary for partnerships and $\mathrm{S}$ corporations to keep two separate basis records-one for federal purposes and one for Kansas purposes.

The Attorney General has specifically addressed the section 37 issue in Attorney General Opinion No. 2012-27. The Attorney General was asked whether the ambiguities embodied in section 37 are so severe that it - and perhaps the paragraph (xx) subtraction in general-cannot be implemented, therefore invalidating at least a portion of $\mathrm{HB} 2117 .^{206}$ The Attorney General's answer is "no."207 At one point in the opinion, the Attorney General states that "[s]ection 37(a) limits adjustments to a partner's basis to those provided in Internal Revenue Code $\S$ 733."208 Later in the opinion, however, the Attorney General states that Section 37 "may" exclude adjustments other than that provided by IRC $\S 733$, "but it does not lack sufficient detail to determine a partner's tax basis." 209 The Attorney General concludes that "the language of ... HB 2117 is sufficient to implement non-wage business income tax exemptions." 210

The authors understand that the Department of Revenue does not intend to issue an interpretation of section 37, but will instead seek clarification by the 2013 Legislature.

\section{Potential Solutions}

Section 37 plays a central role in the application of the new tax regime to partnerships and S corporations. The uncertainty surrounding its interpretation raises serious concerns. Despite the Attorney General's opinion, it will be important for the 2013 Legislature to clarify the intent and meaning of section 37.

The Attorney General has been asked whether legislative modification of section 37 would be unconstitutional if retroactive to the

\footnotetext{
206. See Att'y Gen. Op. No. 2012-27, at 4 (Nov. 2, 2012), http://ksag.washburnlaw.edu/ opinions/2012/2012-027.pdf.

207. Id.

208. Id. at 3.

209. Id. at 5.

210. Id.
} 
beginning of 2013. ${ }^{211}$ The Attorney General's answer is "no," even if the result is an increase in income tax liability. ${ }^{212}$

Although the issues raised by section 37 could be resolved in a variety of ways, either of two approaches seems most likely.

\section{a. Repeal}

One approach would be total repeal of section 37. This would assure full exemption for qualifying partnership and S corporation income when earned by the entity, when distributed to partners or shareholders, and when realized as a component of the gain from the sale of $\mathrm{S}$ corporation stock or an interest in a partnership.

\section{b. Prohibition of Upward Basis Adjustments}

Alternatively, the legislature could amend section 37 to provide that, for Kansas income tax purposes, no upward basis adjustment can be made for entity earnings under IRC $\S 705(\mathrm{a})(1)(\mathrm{A})$ and (B) or $\S$ 1367(a)(1)(A) and (B), while all other adjustments to basis provided by the Internal Revenue Code would be honored. This approach would confirm that the intent of the legislature is to grant only deferral of taxation, not permanent forgiveness.

A change of this kind would make the meaning of section 37 unambiguous, and it would be clear that the basis would be increased upon a contribution of further capital to a partnership or S corporation. As explained above, however, this approach would largely eliminate the benefits of the paragraph (xx) subtraction in the case of service partnerships, such as law firms. Although income would not be taxed when earned by the partnership, the income would be taxed when distributed to partners (except to the extent of the basis created by the partner's capital investment in the partnership).

In a partnership where the partners make a substantial investment, distribution of income to a partner would be tax free up to the amount of the partner's basis, but any further distribution would be taxed. The earnings in excess of basis would also be taxed upon sale of the partner's partnership interest.

211. See id. at 3.

212. See id. at 4. The Attorney General's conclusion is based on the United States Supreme Court's decision in United States v. Carlton, 512 U.S. 26 (1994). Id. 
This approach, however, would create a stark discrimination between independent contractors on the one hand, and partners or S corporation shareholders on the other. For example, assume that Tad is a lawyer practicing alone and earning \$100,000. Tad reports his income on Schedule C, and the paragraph (xx) subtraction shelters the entirety of his income from Kansas tax. This is true even if Tad consumes all of his law practice income. If Tad creates a partnership with Bill, however, the partnership rules apply, and section 37, as amended, would prevent any basis increase reflecting the partnership's earnings. Bill's basis for his partnership interest would remain at zero. If the partnership distributes Bill's share to him, Bill would have a Kansas AGI of $\$ 100,000$. Therefore, Bill would be taxed on the entirety of the $\$ 100,000$ distribution. Simply by becoming a partner, Bill will have subjected the entirety of his income to Kansas tax.

This result would create a strong deterrent to the use of partnerships, LLCs, and S corporations, all of which provide nontax benefits to their owners, often including limited liability against the claims of creditors. This would also result in an unjustified difference in treatment between otherwise similarly situated taxpayers.

\section{PART FIVE: BUDGETARY IMPACT AND EQUITY CONSIDERATIONS}

Given the magnitude of the changes brought about by HB 2117, it should not be surprising that the legislation spawned vigorous debate during its consideration and after its enactment. As explained below, proponents of the legislation maintain that the rate reductions and the reduced tax burdens on some business activities will spur economic growth within Kansas. ${ }^{213}$ Opponents cite concerns about the impact of reduced revenues on state-sponsored programs, ${ }^{214}$ such as education, health, and social programs. Opponents have also raised equity concerns. These concerns, along with the potential revenue effects of the legislation, are discussed below.

213. See, e.g., Press Release, supra note 136.

214. See, e.g., Brent D. Wistrom, Governor Signs Bill for Massive Tax Cuts, WiChITA EAGLE, May 23, 2012, http://www.kansas.com/2012/05/22/2344393/governor-signs-bill-for-massive.html; Barb Shelly, Sam Brownback Signs Budget-Busting Income Tax Bill, KANSASCITY.COM: MidwEST VOICES (May 2012), http://voices.kansascity.com/entries/sam-brownback-signs-budget-bustingincome-tax-bill/. 


\section{A. Revenue Effects}

Estimates of the effect that HB 2117 will have on Kansas tax revenue vary widely. This is not surprising. Even the process of choosing the revenue baseline-the benchmark with which future revenue increases or decreases are compared—can lead to disagreement. Projections based on "static" assumptions, which do not take into account taxpayers' likely behavioral responses to changes in the tax law, as opposed to "dynamic" calculations, which do take into account behavioral reactions such as shifts in consumption and investment, ${ }^{215}$ can lead to dramatically different estimates. The time period over which the estimates are calculated also affects the results.

The Supplemental Note for HB 2117 prepared by the nonpartisan Legislative Research Department indicates that HB 2117 will reduce Kansas tax revenue by the following amounts ${ }^{216}$ :

\begin{tabular}{|c|c|}
\hline Fiscal year & (Millions of Dollars) \\
\hline 2013 & 231.2 \\
\hline 2014 & 802.8 \\
\hline 2015 & 824.3 \\
\hline 2016 & 854.2 \\
\hline 2017 & 892.9 \\
\hline 2018 & 933.7 \\
\hline
\end{tabular}

To put these numbers into context, Kansas government revenue for the fiscal year ending June 30, 2012, was $\$ 6.4$ billion. $^{217}$ Therefore, if the Legislative Research Department's estimates are correct, the annual reduction in revenue each year from 2014 through 2018 will be approximately $12 \%$ to $15 \%$ of the fiscal 2012 revenue level.

The Brownback Administration disagrees with the above estimates. The Administration argues that lower taxes on profits of noncorporate entities will attract new businesses to Kansas and cause Kansas

215. Joint Committee Revenue Estimation Process, JOINT COMMITTEE ON TAX'N, https://www.jct.gov/about-us/revenue-estimating.html (last visited Nov. 11, 2012); see also Alan J. Auerbach, Dynamic Revenue Estimation, J. ECON. PERSP., Winter 1996, at 141, 144 (defining dynamic revenue estimation as including "predicted macroeconomic effects" of revenue policies and static revenue estimation as excluding such effects).

216. KAN. LEGISLATIVE RESEARCH DEP’T, supra note 19, at 4-2117.

217. Kan. Legislative Research DeP’T, State General Fund ReCEIPTs: FY 2012, at 2 (2012), http://skyways.lib.ks.us/ksleg/KLRD/SGF/2012_SGF_June_Receipts.pdf. 
businesses to increase capital investment and hire additional employees. $^{218}$ Expanding the wage base, according to the Administration, will offset much of the potential revenue loss. ${ }^{219}$ In fact, the press release accompanying Governor Brownback's signing of HB 2117 states that "Dynamic projections show the new law will result in 22,900 new jobs, give $\$ 2$ billion more in disposable income to Kansans and increase population by 35,740, all in addition to the normal growth rate of the state., 220

This Article does not seek to defend or attack either set of estimates. We note only that the revenue effects of HB 2117 will be felt soon. While individual tax returns for 2013 are not due until April 15, 2014, employers will incorporate the tax rate reductions into their withholding calculations beginning in January of 2013. Moreover, because much of the income of independent contractors, partnerships, LLCs, S corporations, and trusts will be exempt from tax beginning January 1, 2013, estimated state income tax payments are likely to decline dramatically, beginning with the April 15, 2013, payment. Thus, one can expect that, at least in the short run, revenue will likely decline. In fact, the Governor has stated publicly that he expects state income tax revenues to decline in 2013 by nearly $\$ 50$ million, but rebound in subsequent years. ${ }^{221}$

\section{B. Equity Considerations}

Many commentators have raised concerns about the effect HB 2117 will have on the distribution of tax burden across income classes and on the potential for unequal treatment of similarly-situated taxpayers. We briefly address these concerns below.

218. See Wistrom, supra note 214 ("Brownback said the income tax relief will make Kansas more competitive and generate tens of thousands of jobs.").

219. See id. (noting that the Brownback Administration is relying on future economic and population growth in Kansas to make the legislation a success).

220. Press Release, supra note 136. But see KAn. ECON. Progress CounciL, OvERview: 2012 KANSAS INCOME TAX LEGISLATION 7-9, 15 (2012), http://ksepc.org/wp-content/uploads/2012/09/ Tax_Legislation_Update_October2012.pdf (citing studies calling into question the Administration's claims about job growth and economic growth).

221. Governor Sam Brownback, Economic Growth and Kansas Tax Policy, 2012 Anderson W. Chandler Lecture (Sept. 10, 2012). 


\section{Horizontal Equity Concerns}

Policymakers often cite equity, or fairness, considerations when analyzing tax systems. Equity within the field of tax policy has two dimensions: horizontal equity and vertical equity. ${ }^{222}$ Horizontal equity mandates equal tax burdens for similarly-situated taxpayers. ${ }^{223}$ Part III of this article raised some horizontal equity concerns as between service providers who are employees and service providers who may be able to restructure their positions so that their income qualifies for the paragraph (xx) subtraction. But other examples exist. A cardiologist who is a member of a partnership will pay no Kansas tax on her income, while a cardiologist who is a hospital employee will pay state income tax on the entirety of her income. Similarly, a prosecutor who is an employee of a city or county will be fully taxed on her income, while defense counsel who are sole proprietors or partners will not be taxed.

Taxing all employees while freeing independent contractors and partners from tax creates a situation in which taxpayers doing the same kind of work will be subject to different tax burdens. For example, consider the case of a professional who provides accounting services. The nature of services performed by an accountant typically remains the same whether the practitioner performs those services as an employee, a solo practitioner, or a partner, but the tax consequences will vary dramatically. The employee will be taxed, while the solo practitioner or partner doing the same work will not. Some employees will be able to sever the employment relationship and practice their trade as independent contractors, but the vast majority of employees will lack such opportunities.

In contrast to the approach adopted by Kansas, federal tax law is generally designed to ensure that all personal service income is taxed in the same way for income tax purposes, regardless of whether it is earned

222. Stephen W. Mazza \& Tracy A. Kaye, Restricting the Legislative Power to Tax in the United States, 54 AM. J. COMP. L. 641, 651 (2006) (citing OfFICE OF THE SEC'Y, DEP'T OF THE

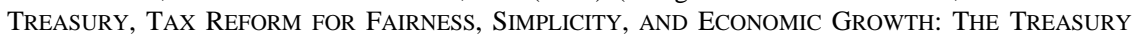
Dep’t Report to the President, OVerview, Doc. No. 239, Vol. 1 (1984)).

223. Id. at 655; see also JOINT COMMITTEE ON TAXATION, GENERAL EXPLANATION OF THE TAX REFORM ACT OF 1986 (H.R. 3838, 99 ${ }^{\text {TH }}$ CONGRESS; PuBLIC LAW 99-514) 7 (1987) (noting that horizontal equity was one of Congress's objectives in reforming the Internal Revenue Code). Not all commentators agree that horizontal equity is a worthwhile goal. See, e.g., Nancy C. Staudt, The Hidden Costs of the Progressivity Debate, 50 VAND. L. REV. 919, 925-32 (1997) (arguing that horizontal equity is impossible to define empirically and that the concept is inconsistent with efficiency concerns). 
as an employee, as an independent contractor, or as a partner. The most important dichotomy drawn for federal tax purposes is between ordinary income, which includes profits from labor, and capital gain income, which includes primarily income from capital. Only capital gain income is taxed at preferential rates. ${ }^{224}$ While the distinction between ordinary and capital income creates its own horizontal equity concerns, the federal system at least seeks to preserve equity among all service providers, which Kansas's new system does not.

Another horizontal equity concern arises from HB 2117's designation of certain sources of income as exempt from tax-especially real estate rent, mineral royalties, and passive farm rental income. All three of these sources often represent passive investment income, not unlike interest, dividends, and capital gains, which generally remain fully subject to Kansas income tax under HB 2117 as interpreted by the Department of Revenue. ${ }^{225}$ Some investors buy stocks and bonds; others may purchase rental real estate, mineral interests, or farm property intended for rental. It is not clear why the former should be taxed while the latter are not.

Much of the disparity in treatment among taxpayers arises from the fact that the paragraph (xx) subtraction isolates tax benefits based on source and entity, rather than the nature of the underlying income. Why the drafters adopted this approach is uncertain, although the Administration's statement that the new law helps small business owners ${ }^{226}$ indicates that this group was the prime target. As noted before, however, the legislation is not necessarily tailored to small businesses, and there is no limit on the amount of income that can qualify for preferential treatment. To the extent that the Kansas Legislature

224. See I.R.C. § 1(h) (2006). HB 2117 rejects the ordinary versus capital dichotomy even though many commentators agree that reduced tax rates on capital gain income have some stimulative effect on the economy, at least as compared to a tax system without these rate preferences. See, e.g., Congressional Budget OfFice, EfFects of LOWER Capital Gains TAXES ON ECONOMIC GROWTH 1 (1990), http://www.cbo.gov/sites/default/files/cbofiles/ftpdocs/ 77xx/doc7767/90-cbo-033.pdf (summarizing ways in which lower capital gains tax rates could affect economic growth, including "improving incentives for entrepreneurship and risk-taking”). Because of how the legislature wrote the statute, exempting income reported on specific IRS forms and schedules, gain from the sale of farm property and assets used in a trade or business does not qualify for the exemption even if the entity selling the assets is a partnership, S corporation, trust, or estate. See supra Parts II.A.4.b.ix, II.A.4.c.

225. Kan. Rev. Rul. 19-2012-02, at 3-4, http://ksrevenue.org/taxnotices/RevRul19-2012-02.pdf. As noted in Part II.A.4.b.vii, if a sole proprietor, partnership, or S corporation is in the business of lending money, interest derived from the business can qualify for the paragraph (xx) subtraction.

226. See Press Release, supra note 136. 
intended HB 2117 to target income generated by entrepreneurs, in the hope that lowering rates on their income would encourage further investment and expand the employment market, the proxy they chose to identify these potential job creators is less than perfect. There is no direct link between many of the sources of passive income identified in the HB 2117 for preferential treatment and economic growth; nor is it clear that all independent contractors and partners are more entrepreneurial than their employee counterparts.

\section{Vertical Equity Concerns}

HB 2117 also raises vertical equity concerns. Policymakers describe the goal of vertical equity as the imposition of appropriately different tax burdens on taxpayers in different economic circumstances. ${ }^{227}$ For federal income tax purposes, vertical equity is achieved primarily through a graduated, progressive rate structure: as the amount of the taxpayer's taxable income increases, the tax rate that applies to higher levels of income also increases. ${ }^{228}$ While not all commentators agree that vertical equity is a worthwhile goal, ${ }^{229}$ it is often defended on the ground of ability to pay: those who have a higher capacity to pay taxes should pay a greater percent. ${ }^{230}$ Another argument for progressive taxation is that of marginal utility. An additional $\$ 1,000$ means a great deal more to a taxpayer earning $\$ 20,000$ than it does to a taxpayer earning $\$ 100,000$.

The progressivity of any state's tax regime depends not just on the tax rates applicable under the state's income tax, but also on the extent to which the state, county, and local governments utilize different types of taxes to generate revenue. ${ }^{231}$ Therefore, in determining whether a state's overall tax system is progressive or regressive, all taxes must be considered.

\footnotetext{
227. See Mazza \& Kaye, supra note 222, at 651 (citing Staudt, supra note 223, at 933).

228. See id. at 651-52.

229. See id. at 652 (noting that some tax scholars "oppose a progressive tax system [because] it complicates the tax code, encourages tax avoidance schemes, and discourages productivity" (citing WAlter J. Blum \& Harry Kalven, JR., The Uneasy CASE FOR PROgRessive TAXATION 14-15, 21 (1953); Jeffrey A. Schoenblum, Tax Fairness or Unfairness? A Consideration of the Philosophical Bases for Unequal Taxation of Individuals, 12 AM. J. TAX POL’y 221 (1995))).

230. See Blum \& KaLVEN, supra note 229, at 64-68; Schoenblum, supra note 229, at 233-36.

231. CARl Davis ET AL., InSt. ON TAXATION \& ECON. Policy, Who PAYs? A Distributional ANAlysis OF THE TAX SySTEMS IN All 50 StATES 4-5 (3d ed. 2009), www.itepnet.org/whopays3. pdf.
} 
Ad valorem property taxes, for example, are naturally regressive because lower-income families tend to have a high portion of their assets embodied in their homes. ${ }^{232}$ In Kansas, the property tax is imposed on real estate and certain tangible personal property. ${ }^{233}$ It has no application to intangible investments, such as stocks and bonds. A low-income family that owns a personal residence subject to property tax will likely pay property tax at a higher effective rate as a percent of the family's income than an upper-income family that owns a home and also has significant investment holdings. Even those taxpayers who rent and do not own a residence may not escape paying property tax; landlords can often pass along the tax cost to the renters.

To offset some of the regressive effect of the property tax, states may offer homestead credits or a more targeted property tax refund that is triggered when the property taxes exceed a certain set percentage of the taxpayer's income. ${ }^{234}$ Prior to HB 2117, in fact, Kansas had a homestead credit that was available to both low-income renters and owners who met certain requirements. ${ }^{235}$ HB 2117 eliminated the credit for taxpayers who rent their homes, ${ }^{236}$ making the property tax even more regressive for lower-income taxpayers who rent rather than own their homes.

Sales taxes are also regressive by nature because low-income taxpayers tend to spend a larger share of their income on items subject to sales tax than do higher-income taxpayers. ${ }^{237}$ Not only that, but, sales taxes, because they apply only when a taxpayer consumes, are not levied on the portion of the taxpayer's income that he or she saves. Higherincome taxpayers, therefore, tend to pay a lower effective sales tax on their income because they have higher amounts of savings.

One of the ways states can limit the regressive effects of sales taxes is to exempt staple items, such groceries and medicine. Kansas exempts

\footnotetext{
232. Id. at 9 .

233. KAN. CONST. art. 11, § 1

234. DAVIS ET AL., supra note 231, at 10.

235. See KAn. StAT. AnN. § 79-4501 (Supp. 2011). The credit was available to low-income persons who were disabled, were over age fifty-five, or who housed one or more dependent children under age eighteen. See id. § 79-4502(e). The credit was also available to surviving spouses of active duty military personnel who died in the line of duty. See id.

236. Act of May 22, 2012, ch. 135, secs. 30-35, 2012 Kan. Sess. Laws 1041, 1081-86.

237. See Eric Kades, Drawing the Line Between Taxes and Takings: The Continuous Burdens Principle, and its Broader Application, 97 NW. U. L. REV. 189, 240 (2002) (noting that a rationale behind certain exemptions from sales tax is the "generally acknowledged fact that the poor spend a larger portion of their income than the wealthy" on items like food).
} 
prescription drugs, ${ }^{238}$ but not food. Before the legislature enacted HB 2117, however, Kansas did offer a sales tax refund credit for low-income taxpayers who were elderly, disabled, or cared for a dependent child. ${ }^{239}$ HB 2117 repealed this tax credit, ${ }^{240}$ eliminating the only element of the sales tax that was progressive. As a result, beginning January 1, 2013, Kansas will join Alabama and Mississippi as the only states that impose sales tax on purchases of food but do not provide relief for low-income persons. $^{241}$

To balance out the regressive effects associated with property and sales taxes, states often rely on a progressive income tax. ${ }^{242}$ Income taxes can help make a state's overall tax regime less regressive by incorporating elements such as a graduated tax rate schedule, expanded tax brackets, and high standard deduction amounts. HB 2117 eliminates many of the progressive features that previously existed under the Kansas income tax. For instance, by reducing the number of income tax rate brackets and reducing the taxable income figure at which the highest rate applies, HB 2117 decreases the level of progressivity within the state's income tax. ${ }^{243}$ Under HB 2117 the Kansas income tax will be close to a flat tax, with the highest marginal tax rate beginning at only $\$ 30,000$ of taxable income for joint returns and $\$ 15,000$ for single filers. Increasing the standard deduction amounts helps offset some of the loss of progressivity, but the increases allowed by HB 2117 apply only to those filing a joint return or as a head of household.

The Legislature did retain the refundable earned income credit, which gives some low-income taxpayers a refund even when the taxpayer pays no state income tax. ${ }^{244}$ On the other hand, HB 2117 eliminated the income tax credit for child and dependent care expenses incurred by those who need care for children and other dependents to retain employment. $^{245}$

\footnotetext{
238. KAN. STAT. ANN. § 79-3606(p).

239. Id. §§ 79-3633 to -3639a (1997 \& Supp. 2011).

240. See Sec. 40, 2012 Kan. Sess. Laws at 1088 (repealing KAn. StAT. AnN. §§ 79-3633 to 3639).

241. INST. ON TAXATION \& ECON. POLICY, supra note 3.

242. DAVIS ET AL., supra note 231, at 5.

243. Under prior law, the differential between the highest and lowest income tax rates was 2.95\%. See Kan. Stat. AnN. § 79-32,110 (Supp. 2011). The rate differential under HB 2117 is only $1.9 \%$. See Sec. 10, § 79-32,110, 2012 Kan. Sess. Laws at 1050-51. The legislation also cut in half the taxable income figure at which the higher rates apply. See id.

244. KAN. STAT. ANN. § 79-32,205.

245. See Sec. 40, 2012 Kan. Sess. Laws at 1088 (repealing KAN. STAT. AnN. § 79-32,111a).
} 
It seems virtually certain that the paragraph (xx) subtraction, which exempts many types and sources of income, will transform the Kansas income tax into a regressive system, with lower-income Kansans cumulatively paying a higher percentage of their income in tax than will higher-income Kansans. There is no limit on the amount of income that can be exempted by paragraph (xx). Large business enterprises owned by individuals or small groups can readily be structured as partnerships, LLCs, or S corporations, thereby escaping tax liability. Many highincome professionals, such as physicians, will be exempt. Wealthy Kansans who invest in rental real estate and mineral interests will be off the tax rolls. Meanwhile, every employee in the state will remain subject to the income tax if the employee's income exceeds the personal exemption and standard (or itemized) deduction. Final conclusions as to regressivity will not be possible until HB 2117 has been in effect for some time, but the structure of HB 2117 strongly suggests that the Kansas income tax will be transformed from mildly progressive to substantially regressive. According to the Institute on Taxation and Economic Policy, based on 2011 income levels, the full effect of the new legislation will be to increase taxes on the bottom 20\% of Kansas taxpayers by $1.3 \%$ per year, or on average $\$ 148{ }^{246}$ By contrast, the new legislation drops the tax on the wealthiest $1 \%$ of Kansas taxpayers by $2 \%$, or on average $\$ 21,087$ per return. ${ }^{247}$

According to one study, before the enactment of HB 2117, Kansas had one of the least regressive state and local tax systems in the United States. $^{248}$ HB 2117, however, not only eliminates many of the progressive elements of the Kansas income tax, with only the earned income tax credit surviving, but it also replaces the current system with an income tax regime that is itself likely to be regressive. ${ }^{249}$ As a result, all three of the principal Kansas taxes-property, sales, and incomewill be regressive. The new Kansas tax system, taking all elements into account, may be among the most regressive in the nation.

246. INST. ON TAXATION \& ECON. POLICY, supra note 3.

247. Id.

248. Fred Thompson et al., Ranking State Tax Systems: Progressivity, Adequacy, Efficiency, in SUSTAINING THE STATES (forthcoming), manuscript fig.1 at 3, available at http://ssrn.com/abstract= 2159486.

249. See InSt. ON TAXATION \& ECON. POLICY, supra note 3 (describing how poorer Kansans will have to pay more taxes and the wealthier less under the new legislation). 


\section{PART SIX: CONCLUSION}

HB 2117 includes more than forty changes in existing law. Already the Kansas Department of Revenue has issued over twenty interpretations of the new law. Despite that, the meaning of some important provisions of HB 2117 remains uncertain, and it will be important for the 2013 session of the Kansas Legislature to clarify those provisions.

HB 2117 is revolutionary in its impact on taxpayers. It sharply lowers income tax rates and brings the Kansas income tax closer to being a flat tax, with only modest progressivity. By exempting from tax many types and sources of income, it creates disparities between similarly situated taxpayers providing services, depending on whether the taxpayer is an employee on one hand, or an independent contractor or partner on the other. It also creates disparities between similarly situated taxpayers depending on whether a taxpayer invests in stock and bonds or in mineral interests and rental real estate. At the same time it limits or removes important credits that have benefitted many low-income Kansans. The result is likely to be a Kansas tax system in which all three major taxesproperty, sales, and income-have a regressive impact, requiring lowerincome Kansans to pay taxes that represent a greater portion of their income than will be paid by upper-income Kansans.

The Legislative Research Department has estimated that HB 2117 will substantially reduce Kansas tax revenues. Governor Brownback, by contrast, believes that the new tax system will buoy the Kansas economy and create jobs, thereby benefitting all Kansans, regardless of income level. The Governor puts it this way: “Today's legislation will create tens of thousands of new jobs and help make Kansas the best place in America to start and grow a small business. Now is the time to grow our economy, not state government, that's what this tax cut will do."250

January 1, 2013, the effective date of HB 2117, begins a new era in Kansas history.

250. Press Release, supra note 136 (internal quotation marks omitted). 